\title{
Investigating the local-scale influence of sea ice on Greenland surface melt
}

\author{
Julienne C. Stroeve ${ }^{1,2}$, John R. Mioduszewski ${ }^{3}$, Asa Rennermalm ${ }^{4}$, Linette N. Boisvert ${ }^{5}$, Marco Tedesco ${ }^{6}$, and \\ David Robinson ${ }^{4}$ \\ ${ }^{1}$ National Snow and Ice Data Center, Cooperative Institute for Research in Environmental Sciences, University of Colorado, \\ 449 UCB, Boulder, CO 80309, USA \\ ${ }^{2}$ Centre for Polar Observation and Modelling, University College London, Department of Earth Sciences, Gower Street, \\ London, WC1E6BT, UK \\ ${ }^{3}$ Center for Climatic Research, University of Wisconsin - Madison, 1225 W. Dayton St., Madison, WI 53706, USA \\ ${ }^{4}$ Department of Geography, Rutgers, State University of New Jersey, 54 Joyce Kilmer Avenue, Piscataway, NJ 08854-8045, \\ USA \\ ${ }^{5}$ NASA Goddard Space Flight Center, Greenbelt, MD 20771, USA \\ ${ }^{6}$ Lamont-Doherty Earth Observation, Columbia University, Palisades, NY 10964-8000, USA
}

Correspondence to: Julienne Stroeve (stroeve@nsidc.org)

Received: 23 April 2017 - Discussion started: 5 May 2017

Revised: 8 August 2017 - Accepted: 14 August 2017 - Published: 23 October 2017

\begin{abstract}
Rapid decline in Arctic sea ice cover in the $21 \mathrm{st}$ century may have wide-reaching effects on the Arctic climate system, including the Greenland ice sheet mass balance. Here, we investigate whether local changes in sea ice around the Greenland ice sheet have had an impact on Greenland surface melt. Specifically, we investigate the relationship between sea ice concentration, the timing of melt onset and open-water fraction surrounding Greenland with ice sheet surface melt using a combination of remote sensing observations, and outputs from a reanalysis model and a regional climate model for the period of 1979-2015. Statistical analysis points to covariability between Greenland ice sheet surface melt and sea ice within Baffin Bay and Davis Strait. While some of this covariance can be explained by simultaneous influence of atmospheric circulation anomalies on both the sea ice cover and Greenland melt, within Baffin Bay we find a modest correlation between detrended melt onset over sea ice and the adjacent ice sheet melt onset. This correlation appears to be related to increased transfer of sensible and latent heat fluxes from the ocean to the atmosphere in early sea ice melt years, increasing temperatures and humidity over the ice sheet that in turn initiate ice sheet melt.
\end{abstract}

\section{Introduction}

The shrinking sea ice cover is one of the most striking features of Arctic climate change (e.g., Stroeve et al., 2012; Serreze et al., 2007). Since the late 1970 s, the sea ice extent (SIE) has declined by more than $40 \%$ in September, with smaller yet statistically significant negative trends in other months. These negative trends have been linked to the observed increases in atmospheric $\mathrm{CO}_{2}$, with the prospect of the Arctic Ocean becoming seasonally ice free before the middle of this century if current emission rates continue (Notz and Stroeve, 2016). At the same time, the Greenland ice sheet (GrIS) has experienced increased summer melt (e.g., Tedesco et al., 2011; Fettweis et al., 2011) and an increasingly negative mass balance (Khan et al., 2015). While earlier studies found GrIS mass loss to be balanced by ice discharge and ice melt (van den Broeke et al., 2009), newer evidence shows surface melting is now contributing $84 \%$ to the mass loss since 2009 (Enderlin et al., 2014). It has further been suggested that surface melting will dominate Greenland's contribution to sea level rise throughout the rest of this century (Enderlin et al., 2014; Fyke et al., 2014a). Similar to the sea ice environment, an anthropogenic signal has been identified in the observed changes of GrIS surface mass balance (SMB) (Fyke et al., 2014b). 


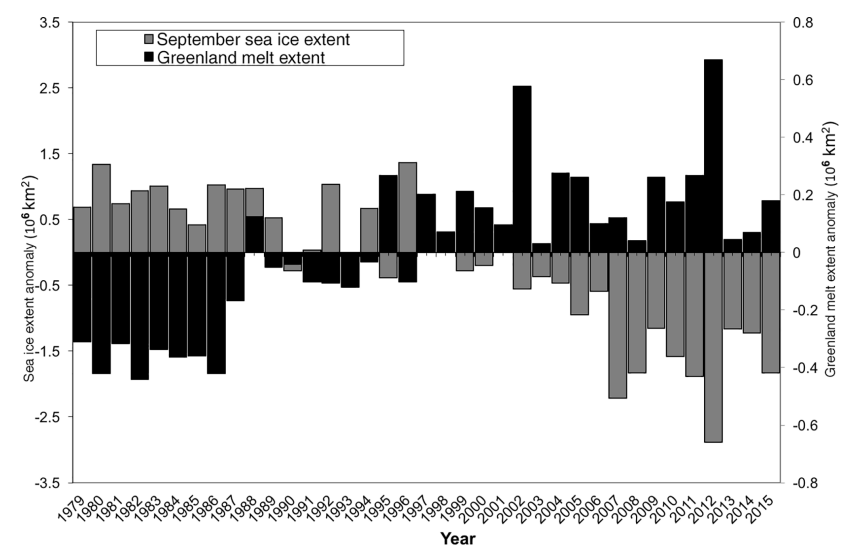

Figure 1. Time series of September sea ice extent and Greenland surface melt extent anomalies from 1979 to 2015.

While both the GrIS and sea ice environments are responding to anthropogenic warming (Hanna et al., 2008), changes in atmospheric circulation patterns that favor increased sea ice loss and GrIS melt have also played a role. Analysis of mid-tropospheric summer (JJA) sea level pressure (SLP) reveal statistically significant increases over Greenland and north of the Canadian Arctic Archipelago coupled with significant negative trends over northern Eurasia and Canada from 1979 to 2014 (Serreze et al., 2016; Bezeau et al., 2015), dominated by a clear shift in the last decade (2005 to 2014) towards large positive SLP anomalies over the central Arctic Ocean and Greenland. This pattern favors both summer sea ice loss (e.g., Wang et al., 2009; Ogi and Wallace, 2007) and Greenland surface melt (Hanna et al., 2013; Mioduszewski et al., 2016; Ballinger et al., 2017). Additionally, advection of warm and humid air masses appears to be the primary factor initiating sea ice melt onset (MO) (Boisvert and Stroeve, 2015; Mortin et al., 2016). Anomalous GrIS melting also appears to coincide with increasing water vapor transport to the ice sheet (Mattingly et al., 2016). Thus, it is not surprising that there is a strong inverse correlation between GrIS melt intensity (defined by Tedesco et al., 2007) and the pan-Arctic September SIE ( $r=-0.83$ from 1979 to 2015) (Fig. 1). Detrended data reveal a substantially weaker inverse relationship ( $r=-0.27$ ), yet the year-to-year variability between September SIE and GrIS melt remains highly correlated $(r=-0.69)$. This would suggest that atmospheric processes fostering a high melt year also tend to foster more summer sea ice loss and vice versa.

What about local-scale feedbacks? Changes in sea ice have strong local-scale influences on the Arctic climate through enhanced transfer of heat and moisture between the ocean and atmosphere, resulting in amplified Arctic warming (e.g., Serreze et al., 2009; Screen and Simmonds, 2010). This is mostly manifested during the cold season, as warming of the ocean mixed layer during summer results in increased sensible and latent heat transfer from the ocean to the atmosphere (Boisvert et al., 2015). Other studies have linked sea ice loss to atmospheric warming in surrounding areas during other times of the year as well (Comiso et al., 2002; Hanna et al., 2004; Bhatt et al., 2010; Serreze et al., 2011). Sea ice loss is additionally tied to increased tropospheric moisture, precipitation, cloud cover, surface temperature, and decreased static stability (Deser et al., 2000; Rinke et al., 2006; Francis et al., 2009; Serreze et al., 2009; Kay et al., 2011; Screen and Simmonds, 2010; Stroeve et al., 2011; Overland and Wang, 2010; Cassano et al., 2014). Water vapor or moisture increases surface melting through its role in cloud formation and, as a greenhouse gas, results in increased downward longwave radiation and precipitation (Bennartz et al., 2013; Doyle et al., 2015; van Tricht et al., 2016).

This study examines whether or not local changes in the sea ice environment around Greenland are already impacting GrIS meltwater production and therefore SMB variations. First, we identify regions of sea ice concentration (SIC) and GrIS melt covariability by applying the singular value decomposition method. We hypothesize that regions of covariability will have consistent trends in sea ice cover and melt production, as well as consistent trends in spring MO and fall freeze-up (FO). In a second step, this hypothesis is examined with a spatial analysis of trends for the entire study domain. Third, we investigate whether a plausible mechanism for local-scale influence between SIC and GrIS is present. Specifically, we hypothesize that the mechanism for the local-scale influence is controlled by positive turbulent fluxes from the SIC regions. Therefore, anomalous turbulent fluxes should be larger in years with early sea ice melt onset than in later years in regions of covariability. In turn, these turbulent heat fluxes should result in increased specific humidity and near-surface temperature over the GrIS, which should be reflected in positive net longwave radiation anomalies. Finally, a detailed analysis, restricted to the region with evidence of local-scale influence, is performed. In this analysis, we examine the hypotheses that the timing of turbulent heat flux anomaly perturbations over reduced sea ice areas precedes changes in GrIS humidity and temperature and that wind patterns in early melt onset years are favorable for turbulent heat flux transport from the ocean to the ice sheet. Finally, correlation and partial correlation analysis is used to examine the influence of large-scale atmospheric circulation (here represented by the Greenland Blocking Index, GBI).

\section{Data}

\subsection{Sea ice and ice sheet data}

Sea ice and Greenland melt extent/area calculations rely on algorithms applied to satellite passive microwave data from the Nimbus-7 Scanning Multichannel Microwave Radiometer (SMMR: 1978-1987) and the DMSP Special Sensor Microwave/Imagers (SSM/I and SSMIS: 1987 to present). 
Specifically, we use several sea ice metrics derived from the NASA Team SIC algorithm (Cavalieri et al., 1996) and distributed by the National Snow and Ice Data Center (NSIDC). The dataset spans October 1978 to present, providing daily (or every other day during the SMMR era) SIC estimates. Using the SIC, we additionally calculate the open-water fraction (OWF) and the length of the ice-free season, defined as the number of days each year with ice concentration less than $15 \%$ (see Parkinson, 2014).

Changes in the timing of MO and FO, in addition to total melt season length over sea ice, are computed following Markus et al. (2009). This study uses an updated version of the algorithm that bias corrects for inter-sensor calibration issues found between the F17 and F13 sensor and evaluates early melt onset (EMO), corresponding to the first day of $\mathrm{MO}$, the continuous MO, and the continuous FO.

GrIS melt extent is an estimate of the daily spatial extent of wet snow using the Mote et al. (2014) algorithm and distributed by NSIDC. From the binary melt/no melt classification, GrIS MO and FO dates were calculated for each pixel and each year from 1979 to 2015 . We defined the start of the $\mathrm{MO}$ and FO as the first occurrence of a 5-day continuous melt or freeze-up period. Melt duration was calculated as the number of days between MO and FO. EMO was also determined and defined as the first time a spurious melt event lasting at least 1 day was recorded.

Besides mapping the GrIS melt extent and timing of $\mathrm{MO}$ and FO, we use meltwater production and $850 \mathrm{hPa}$ wind as simulated by Modèle Atmosphérique Régional (MAR) v3.2 regional climate model (Tedesco et al., 2013). MAR is a three-dimensional coupled atmosphere-land surface model that uses reanalysis data at its lateral boundaries. In this study, MAR is forced with data from ERA-40 for the period of 1979-2002 and ERA-Interim for the period of 2002-2015 and outputs are produced on a polar stereographic projection with an approximate grid cell size of $25 \times 25 \mathrm{~km}$ to match the passive microwave-derived fields. MAR's atmospheric model is coupled to the 1-D Surface Vegetation Atmosphere Transfer scheme, SISVAT (Gallée and Schayes, 1994; De Ridder and Gallée, 1998), which simulates surface properties and the exchange of mass and energy. SISVAT incorporates a snow model based on the CROCUS snowpack model (Brun et al., 1992). MAR has been validated through comparison with ground measurements (e.g., Lefebre et al., 2003, 2005; Gallée et al., 2005) and satellite data (e.g., Fettweis et al., 2005, 2011; Tedesco et al., 2011; Alexander et al., 2014) and applied to simulate long-term changes in the GrIS SMB and surface melt extent (Fettweis et al., 2005, 2011; Tedesco et al., 2008, 2011; Tedesco and Fettweis, 2012). Data are freely available from an online repository (Tedesco et al., 2015).

Meltwater production was used for grid cells classified by MAR as greater than $99 \%$ ice sheet to mask the tundra region of Greenland. In addition, meltwater production values of less than $1 \mathrm{~mm} \mathrm{day}^{-1}$ in all grid cells were recoded to zero to account for MAR's scaled output. This threshold could

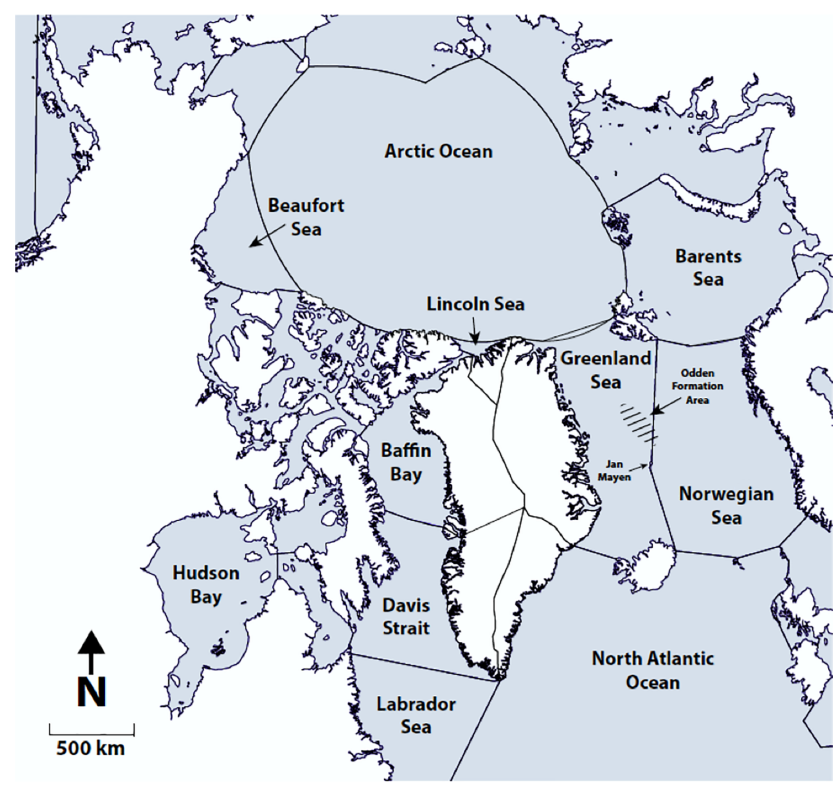

Figure 2. Map of study area, including the six sea ice and Greenland drainage sectors used in this study. The ice sheet regions are named after their adjacent sea (i.e., Davis Strait, Baffin Bay, Lincoln Sea, Greenland Sea, and the North Atlantic). The approximate area where the Odden sea ice used to form is indicated with hatched lines. The ocean boundaries are defined by the International Hydrographic Organization (VLIZ 2005; IHO Sea Areas; available online at http://www.marineregions.org/.)

be considered a conservative approximation of the occurrence of surface melt (Fettweis et al., 2011, Fig. 2). Finally, grid cells were masked in the interior ice sheet where mean monthly meltwater production does not exceed $1 \mathrm{~mm}^{-1} \mathrm{yy}^{-1}$ to account for spurious correlations arising from a very limited number of dates that result in nonzero mean monthly values of meltwater production.

Trends for each pixel (or regional averages) are only computed when at least 30 years of valid data are found at that pixel. This ensures that statistics are not biased by changes in spatial extent of the sea ice or Greenland melt. However, Greenland melt has been observed to extend to higher elevations in recent years, and in 2012 nearly the entire ice sheet experienced melt events (e.g., Nghiem et al., 2012). Regional means are area weighted. Trends are computed using linear least squares and statistical significance is evaluated with a Student $t$ test at the 95 and $99 \%$ levels.

\subsection{Atmospheric data}

Geopotential heights at $500 \mathrm{hPa}$ and hourly $10 \mathrm{~m}$ wind speeds were obtained from NASA's Modern Era RetrospectiveAnalysis for Research and Applications (MERRA) products (Bosilovich et al., 2011; Cullather and Bosilovich, 2011a, b; Rienecker et al., 2011). MERRA is run on a $1 / 2^{\circ}$ latitude by $2 / 3^{\circ}$ longitude global grid with 72 hybrid-sigma vertical 
levels to produce analyses from 1979 to present. MERRA has been evaluated extensively since its release (Cullather and Bosilovich, 2011b; Kennedy et al., 2011; Reichle et al., 2011) and has compared favorably with other reanalysis products in the Arctic (Zib et al., 2012; Cullather and Bosilovich, 2011; Lindsay et al., 2014).

We also utilize atmospheric variables from NASA's Atmospheric Infrared Sounder (AIRS), designed specifically to map atmospheric water vapor content. This instrument has been used in several recent studies to document atmospheric changes and impacts on sea ice in the Arctic (e.g., Boisvert and Stroeve, 2015; Stroeve et al., 2014; Serreze et al., 2016). While the data record is rather short (begins in September 2002), it provides twice daily global coverage at $1^{\circ}$ spatial resolution of several key atmospheric variables, including skin and air temperature, precipitable water, cloud fraction, and specific humidity. In this study we utilize the Level 3 Version 6 skin temperatures, $1000 \mathrm{hPa}$ air temperature, effective cloud fraction, near-surface specific humidity, and total precipitable water. Additional variables derived from AIRS data products include the moisture flux (Boisvert et al., 2013, 2015), turbulent sensible heat flux, and downwelling longwave radiation (Boisvert et al., 2016).

\section{Methods}

\subsection{Region of interest and study periods}

For local assessment of sea ice changes and corresponding ice sheet changes, we define five sea ice and five adjacent ice sheet regions. Since we are examining the potential influence of the ocean on the ice sheet, it makes sense for the ocean regions selected to define the ice sheet boundaries, rather than the other way around. The definition of the sea ice boundaries comes from the International Hydrographic Organization, and we define five sea ice regions: Baffin Bay, David Strait, Lincoln Sea, Greenland Sea, and the North Atlantic together with associated Greenland regions (Fig. 2). For the ice sheet, each region is defined along a topographical divide. While there are many local topographical divides, only those regions that matched the ocean delineations were selected.

We use two study periods. First, we do analysis from 1979 to 2015 when analyzing sea ice, melt extent, and MAR model outputs. Second, AIRS data analysis is applied from 2003 to 2015 since a full year of data collection did not begin until 2003.

\subsection{Relationship between SIC and GrIS melt}

To investigate covariability between summer SIC, GrIS meltwater production, and $500 \mathrm{hPa}$ geopotential heights, singular value decomposition (SVD) was applied to two fields at a time to produce pairs of coupled spatial patterns that explain their maximum mean squared temporal covariance (Bretherton et al., 1992). The advantage of SVD is that it is able to maximize the covariance between the two fields to explicitly show the structure of the covariability.

The temporal evolution of each pair's corresponding pattern in the two datasets is represented by the pair's associated expansion coefficients (ECs), where subscripts GrIS, SIC, and 500 denote the ECs for ice sheet melt, sea ice concentration, and $500 \mathrm{hPa}$ heights, respectively. These ECs were used to calculate heterogeneous correlation (HC) maps, which show the correlation coefficients between each EC and the opposing data field. SVD has widely been used to investigate coupled modes of variability, including relationships between Arctic sea ice and snow cover (Ghatak et al., 2010) and Arctic sea ice and atmospheric variables (Stroeve et al., 2008).

To further investigate how SIC in these regions is related to GrIS melt, SIC for both regions was spatially aggregated, de-trended, and correlated with de-trended time series of GrIS meltwater production and the GBI, respectively (NOAA, 2015). The GBI is defined as the $500 \mathrm{hPa}$ geopotential height field averaged between 20 and $80^{\circ} \mathrm{W}, 60$ and $80^{\circ} \mathrm{N}$ (Fang, 2004; Hanna et al., 2013) and is used as a metric for large-scale atmospheric circulation patterns over Greenland. To remove the influence of the GBI on both SIC and GrIS melt, we performed a partial correlation analysis of SIC in each region and GrIS meltwater production after the trends in GBI were removed (e.g., Cohen et al., 2003).

\subsection{Energy balance}

Following Koenig et al. (2014), the net heat flux into the atmosphere $\left(F_{\text {net }}\right)$ emitted from the ocean is defined by

$F_{\text {net }}=Q_{\mathrm{h}}+Q_{\mathrm{e}}+\mathrm{LW}-\mathrm{SW}$,

where SW is the downward shortwave radiative flux at the surface, $\mathrm{LW}$ is the net upward longwave radiation, $Q_{\mathrm{h}}$ is the sensible heat flux (heat transferred from the surface to the atmosphere by turbulent motion and dry convection), and $Q_{\mathrm{e}}$ is the latent heat flux (heat extracted from the surface by evaporation). If the sum of the four right-hand side terms is positive, there is a net flow of heat from the surface to the atmosphere and vice versa.

Previous studies have looked at the strong seasonality in $F_{\text {net }}$ over the Arctic Ocean (e.g., Serreze et al., 2007), with strong downward fluxes in summer and large upward fluxes in January associated with heat gain and loss, respectively, in the subsurface column. Updated trends from NCEP/NCAR reanalysis confirm that $F_{\text {net }}$ trends are small in winter (January to April), except in the Barents Sea, as a result of reduced sea ice and increased oceanic heat flux (Ornaheim et al., 2016), and within Baffin Bay, again a result of less winter ice cover. Thus, in these two regions there is a transfer of heat from the ocean to the atmosphere during the winter months, which may spread over the sea ice areas and limit winter ice growth. In summer, however (May to August), the 
direction is generally reversed with large heat fluxes from the atmosphere going towards the surface.

In this study we focus on how early sea ice retreat, as indicated by early melt onset during the transition from winter to summer, impacts the heat and moisture fluxes over early formed open-water areas, and whether or not this is sufficient to impact Greenland melt. Towards this end, we composite the turbulent fluxes in Eq. (1) for low and high sea ice years, specific to each individual region analyzed using the AIRS data, with positive fluxes showing energy transfer from the surface to the atmosphere. We use the criteria of anomalies in melt onset exceeding 1 standard deviation $(1 \sigma)$ for each region when compositing. All data are detrended by subtracting the linear trend before computing the composites.

\section{Results}

We begin with an assessment of the large-scale relationship between SIC and Greenland melt and its spatial covariability (4.1). This is followed by an analysis of changes in the sea ice cover surrounding Greenland, in terms of both SIC and OWF (4.2), followed by analysis of the timing of sea ice MO onset and FO and its relationship with Greenland MO (4.3). Finally, turbulent heat and moisture flux changes composited for early and late melt onset years are examined (4.4) and large-scale influences are examined in Sect. 4.5.

\subsection{Relationship between sea ice and Greenland melt}

The leading SVD mode explains the majority of the mean spatial covariance between monthly GrIS meltwater production and SIC in June and July (62 and $73 \%$, respectively) and less than half (42\%) in August. HC maps reveal opposing signs of the correlations between the map pairs (Fig. 3 columns 1 and 2 and columns 3 and 4) indicating an anticorrelation, meaning that increased ice sheet melt extent covaries with decreased sea ice area (it is irrelevant in the HC maps which is positive and which is negative). Specifically, the covariability of GrIS meltwater production and SIC, expressed as correlations on an HC map, shows that sea ice and ice sheet melt strongly covary in two general regions, namely Baffin Bay/Davis Strait in June and a large part of Beaufort Sea in June and July (Fig. 3a and e). In June, SIC in both the Baffin Bay/Davis Strait and the Beaufort Sea regions has strong correlations with $\mathrm{EC}_{\mathrm{GrIS}}(|r|>0.70)$, and GrIS meltwater production is highly correlated with $\mathrm{EC}_{\mathrm{SIC}}$ for the majority of the unmasked ice sheet surface (Fig. 3b). The strong correlation in the Beaufort Sea persists in July but not in Baffin Bay/Davis Strait, and neither exhibits a significant correlation in August (Fig. 3e and i). At the same time, GrIS meltwater production correlations with $\mathrm{EC}_{\text {SIC }}$ are less expansive over the ice sheet in July and August, particularly in southern Greenland (Fig. 3f and j).
In the second SVD analysis of $500 \mathrm{hPa}$ geopotential heights and GrIS meltwater production, the leading SVD mode explains the majority of mean spatial covariance of the two variables in June and July (79 and 60\%, respectively) but less than half in August (37\%), which are similar values to the leading SVD mode for GrIS melt and SIC (Fig. 3c, g, and k). The HC maps show a strong tendency for positive height anomalies centered on the Greenland side of the Arctic, though this area shrinks in July and August (Fig. 3c, g, and k). As before, this spatial pattern covaries with GrIS meltwater production over most of the ice sheet in June but is somewhat more restricted in extent in July and August. While SIC and GrIS melt extent covary regionally, large parts of the same areas of the GrIS melt extent region also covary with $500 \mathrm{hPa}$ geopotential height fields. The similar spatial patterns in GrIS melt covariability with SIC and $500 \mathrm{hPa}$ geopotential height fields suggest that the large-scale circulation may be a dominant explanation for the SIC-GrIS melt covariability. Before this possibility is examined more closely, we analyze trends in SIC and GrIS melt patterns and timing.

\subsection{Changes in the sea ice cover around Greenland}

The above analysis suggests a local-scale influence from SIC on GrIS melt within Baffin Bay and Davis Strait during June. This region of high SIC-GrIS covariability has experienced a sharp drop in SIC since 1979 (Fig. 4). In Baffin Bay and Davis Strait, SIC trends are negative in all seasons and are particularly large in winter (DJF), spring (MAM), and summer (JJA) (Fig. 4a-d). In contrast, SIC trends in the east Greenland Sea are mixed, which may in part explain the lack of covariability within this region. Adjacent to the Greenland's east coast, positive SIC trends occur throughout winter and spring. Further east, reductions in SIC are confined to the area where the Odden used to form (see Fig. 2). During summer and fall, negative SIC anomalies persist along eastern GrIS, though they remain smaller than on the western side. To the north, in the Lincoln Sea region, there is essentially no change in SIC year-round except for slight negative trends in summer.

Negative SIC trends have resulted in longer open-water periods surrounding Greenland (Fig. 4e). Trends in annual open-water days are mostly positive everywhere, with exceptions being the Lincoln Sea, which remains ice-covered year around, and the southern part of Davis Strait towards the Labrador Sea, a region where ice has expanded during recent winters. In some locations within Baffin Bay and the east Greenland Sea the number of open-water days has increased by as much as 30 to 40 days per decade, but regionally averaged trends are generally on the order of 2 weeks per decade.

The strength of the OWF trends and exact timing of when these trends peak around the GrIS reveal large spatial differences (Fig. 5). The largest OWF trends occur in Baffin Bay 


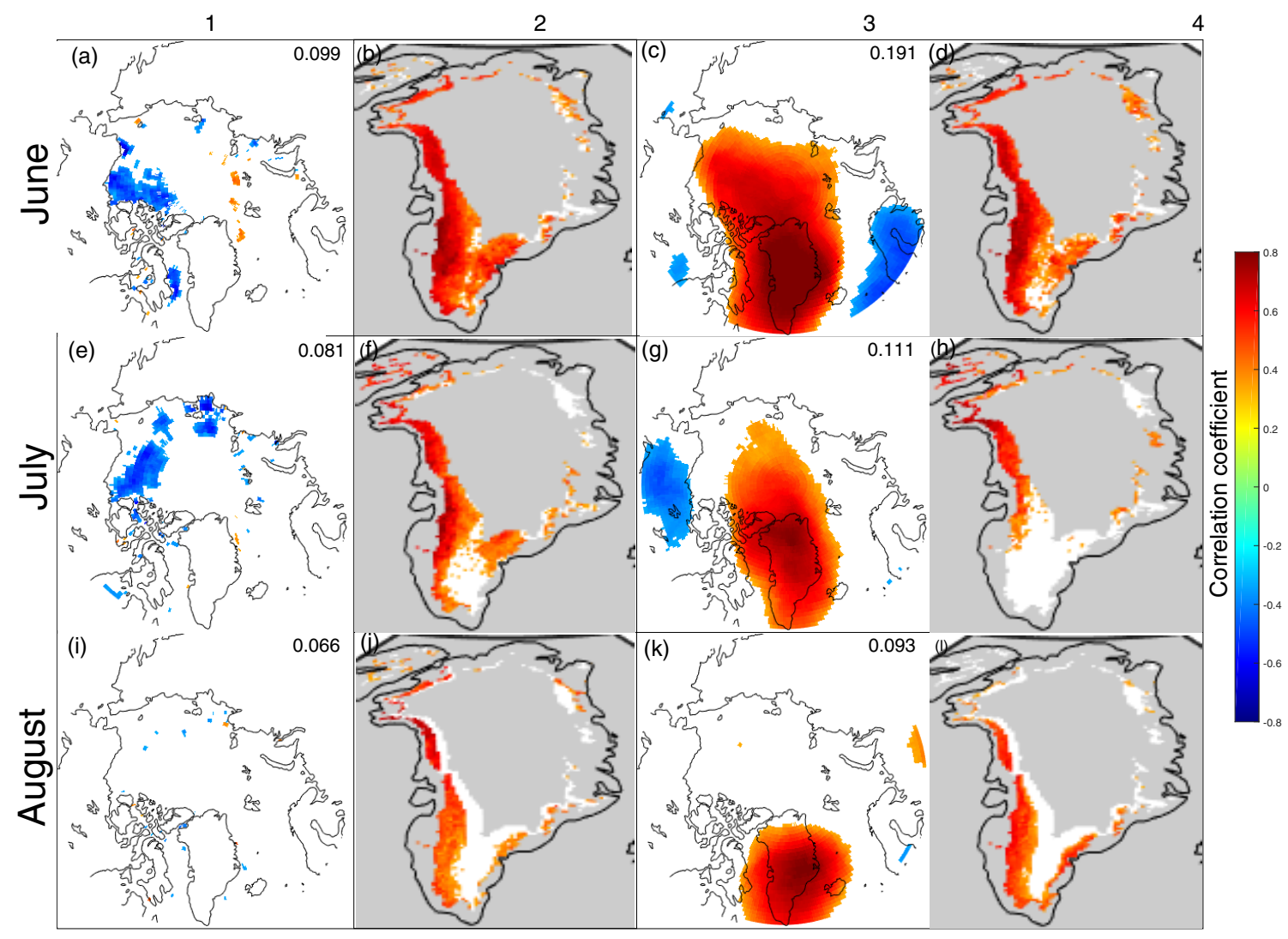

Figure 3. Heterogeneous correlation between variables in the leading SVD mode in JJA. Column 1 is the correlation between sea ice concentration and $\mathrm{EC}_{\mathrm{GrIS}}$. Column 2 is the correlation between meltwater production and $\mathrm{EC}_{\mathrm{SIC}}$. Column 3 is the correlation between $500 \mathrm{hPa}$ geopotential heights and $\mathrm{EC}_{\mathrm{GrIS}}$. Column 4 is the correlation between meltwater production and the $\mathrm{EC}_{500}$. Correlation coefficients are not considered over the masked gray regions, and only correlations significant at $\alpha=0.05$ are shown. All data are anomalies relative to 1979-2015 means with the least-squares trend line removed.

during week 26 (third week of June) and are on the order of $10 \% \mathrm{dec}^{-1}$, with a secondary peak during week 44 (end of October). Further south in Davis Strait, OWFs are positive throughout winter and into July $\left(\sim 5 \% \mathrm{dec}^{-1}\right)$, reflecting both earlier ice retreat and later winter ice formation, with the largest trends during week $52\left(6 \% \mathrm{dec}^{-1}\right)$. East of Greenland, positive OWF trends are found throughout the year in the Greenland Sea but are considerably weaker than found in Baffin Bay and Davis Strait. Finally, Lincoln Sea OWF trends are mostly negative (except in June and August), though trends are generally less than $1 \% \mathrm{dec}^{-1}$, and are not statistically significant. For comparison the Arctic Ocean OWF trends are also shown, showing peak OWF trends around week 38 (mid-September), reflecting the timing of the panArctic sea ice minimum.

\subsection{Changes in the melt season}

We next examine if there is a link between the timing of EMO, MO, and FO over sea ice and over GrIS. The link between MO and the timing of ice retreat has already been established, with correlations between the detrended melt onset and detrended ice retreat dates greater than 0.4 (see Fig. S10; Stroeve et al., 2016).

Climatological regional mean values of EMO, MO, and FO show that melt begins earlier and freeze-up happens later over the sea ice than on the ice sheet and can be largely explained by temperature dependencies on elevation (Table 1). In western Greenland, the continuous MO period for sea ice begins about 9 days earlier than on the ice sheet in the Baffin Bay region and 15 days earlier in the Davis Strait region, whereas ice sheet FO occurs on average in early to midSeptember, compared to the end of October (Baffin Bay) to the end of November (Davis Strait) over the adjacent sea ice. Similarly, in the Greenland Sea region, MO begins around 20 days earlier over the sea ice than on the ice sheet and FO happens about a month later. In contrast, the Lincoln Sea region exhibits similar timing in both $\mathrm{MO}$ and FO, which may be explained by the fact that this is the smallest region, as well as the region furthest north where most melting will only occur at lowest GrIS elevations. Since there is little sea ice in the North Atlantic (e.g., regionally the open-water season lasts 
Table 1. Climatological (1981-2010) mean values in length of open-water season, together with climatological dates in early melt onset (EMO), continuous melt onset (MO), continuous freeze-up (FO), and melt season duration for five sea ice regions (excluding the North Atlantic where little sea ice exists). Corresponding mean dates in MO, FO and duration are also shown for the Greenland drainage basins.

\begin{tabular}{lrrrrr}
\hline Region & $\begin{array}{r}\text { Length of } \\
\text { open water } \\
\text { season (days) }\end{array}$ & $\begin{array}{r}\text { EMO } \\
\text { (day of year) }\end{array}$ & $\begin{array}{r}\text { MO } \\
\text { (day of year) }\end{array}$ & $\begin{array}{r}\text { FO } \\
\text { (day of year) }\end{array}$ & $\begin{array}{r}\text { Melt duration } \\
\text { (days) }\end{array}$ \\
\hline Sea ice regions & & & & & \\
\hline Baffin Bay & 104 & 146 & 155 & 291 & 136 \\
Davis Strait & 220 & 133 & 143 & 321 & 188 \\
North Atlantic & 360 & 110 & 134 & 313 & 178 \\
Greenland Sea & 227 & 143 & 148 & 267 & 119 \\
Lincoln Sea & 0 & 162 & 172 & 232 & 60 \\
\hline Greenland ice sheet drainage regions & & & & 68 \\
\hline Baffin Bay & & 162 & 164 & 232 & 90 \\
Davis Strait & 149 & 157 & 247 & 89 \\
North Atlantic & 143 & 145 & 234 & 65 \\
Greenland Sea & 163 & 166 & 231 & 63 \\
Lincoln Sea & 166 & 167 & 230 & \\
\hline
\end{tabular}

for 360 days), MO and FO dates are not meaningful but generally show values similar to that observed in Davis Strait.

EMO, MO, and FO trends for SIC and GrIS are of the same sign, indicating an overall lengthening of the melt season over the last 37 years in both environments (Fig. 6). Baffin Bay experiences the largest trends towards earlier $\mathrm{MO}$ and later FO, with regionally averaged trends of -8.3 and +7.8 days $\mathrm{dec}^{-1}$, respectively, statistically significant at $99 \%$ confidence (Table 2). This has led to an increase in the melt season length on the order of 16 days per decade. GrIS trends in the same region are typically smaller, especially in regards to the timing of freeze-up (4.6 days $\mathrm{dec}^{-1}$ ) and melt season duration (11.1 days dec ${ }^{-1}$ ). In contrast, larger statistically significant trends in both $\mathrm{MO}$ and FO are seen over the Davis Strait GrIS region, leading to a lengthening of the melt season that is larger than over the adjacent sea ice (18.7 days $\mathrm{dec}^{-1}$ compared to $11.7 \mathrm{days}_{\mathrm{dec}}{ }^{-1}$ ).

On Greenland's eastern side, similar ice sheet/sea ice MO trends are observed, but sea ice FO trends are smaller and not statistically significant. The exception is the North Atlantic region, which exhibits large positive FO trends of 8.9 days $\mathrm{dec}^{-1}$, resulting in an overall increase in melt season duration of 16.3 days dec$^{-1}$. However, given the low frequency of sea ice in this region, caution is warranted when interpreting these trends since ocean dynamics play a large role in the year-to-year variability in these values. Nevertheless, the largest trends in melt season duration over the eastern GrIS are also found in the North Atlantic sec-

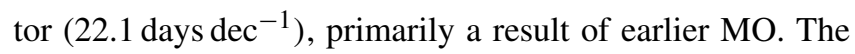
Greenland Sea GrIS sector also exhibits large trends in melt duration (14.4 days $\mathrm{dec}^{-1}$ ), but earlier MO and later FO play a nearly equal role here. Interestingly, the Lincoln Sea GrIS region also displays large trends in melt season duration
(12.7 days $\mathrm{dec}^{-1}$ ), considerably larger than seen over the adjacent sea ice $\left(5.5\right.$ days dec $\left.^{-1}\right)$. While the climatological mean timing of $\mathrm{MO}$ and FO is broadly similar over both the sea ice and the GrIS in the Lincoln Sea GrIS region, there has been a trend towards much later freeze-up $\left(6.8\right.$ days $\left.\mathrm{dec}^{-1}\right)$.

Finally, we examine whether there is synchronicity in the timing of melt onset and freeze-up between the sea ice and the ice sheet. In the Baffin Bay sector, the correlations between the sea ice and ice sheet MO and FO, respectively, exceed $0.6 ; p=0.001$. High correlations $(r>0.6)$ are also seen in the Lincoln Sea sector and for EMO in the Greenland Sea sector $(r=0.6 ; p=0.001)$. Correlations are reduced when MO, FO and EMO records are detrended, yet remain significant in the Baffin Bay and Lincoln Sea regions: detrended correlations for sea ice and the ice sheet EMO, FO, and melt season duration exceed $r=0.5, p=0.001$ in Baffin Bay and the Lincoln Sea in regards to the MO, $p=0.002$. Elsewhere, no significant relationship is found.

\subsection{Impact of sea ice changes on surface energy fluxes}

Next we examine the relationship between early and late MO and variations in atmospheric moisture and heat fluxes using lag correlation and composites for early and late $\mathrm{MO}$ years. We begin with an assessment of the differences in the strength of turbulent fluxes between early and late MO years. All months are shown to allow for both an assessment of what drives early MO over sea ice and to determine how early sea ice MO influences the overlying atmosphere (Fig. 7).

On average, the transfer of latent heat flux occurs from the ocean to the atmosphere year-round in all regions, except the Lincoln Sea in September-May and Baffin Bay in December-February. In Baffin Bay and Lincoln Sea, latent 
Table 2. Trends from 1979 to 2015 in length of open-water season, together with trends in melt onset, freeze-up, and melt season duration for five sea ice regions (excluding the North Atlantic, where little sea ice exists). Corresponding trends in melt onset, freeze-up, and duration are also shown for the Greenland drainage basins. Only values for the continuous melt onset and freeze-up periods are listed. Trends are given as days per decade. Statistical significance of trend at 95 and $99 \%$ are denoted by ${ }^{+}$and $^{++}$, respectively.

\begin{tabular}{|c|c|c|c|c|c|}
\hline Region & $\begin{array}{r}\text { Open water } \\
\text { trend }\left(\text { days dec }{ }^{-1}\right)\end{array}$ & $\begin{array}{r}\text { EMO trend } \\
\text { trend }\left(\text { days dec }{ }^{-1}\right)\end{array}$ & $\begin{array}{r}\text { MO trend } \\
\left(\text { days dec }^{-1}\right)\end{array}$ & $\begin{array}{r}\text { FO trend } \\
(\text { days dec } \\
-1\end{array}$ & $\begin{array}{l}\text { Melt duration } \\
\left(\text { days dec }^{-1}\right)\end{array}$ \\
\hline \multicolumn{6}{|l|}{ Sea ice regions } \\
\hline Baffin Bay & $12.6^{+}$ & $-5.7^{++}$ & $-8.3^{++}$ & $7.8^{++}$ & $16.1^{++}$ \\
\hline Davis Strait & $15.9^{+}$ & $-4.7^{+}$ & $-6.7^{++}$ & $5.0^{++}$ & $11.7^{++}$ \\
\hline North Atlantic & N/A & $-6.9^{++}$ & $-7.3^{++}$ & $8.9^{++}$ & $16.3^{++}$ \\
\hline Greenland Sea & $15.2^{+}$ & $-6.7^{++}$ & $-3.8^{+}$ & 2.1 & $5.9^{+}$ \\
\hline Lincoln Sea & -0.1 & $-4.0^{++}$ & $-3.9^{++}$ & 1.6 & $5.5^{++}$ \\
\hline \multicolumn{6}{|c|}{ Greenland ice sheet drainage regions } \\
\hline Baffin Bay & & $-6.1^{++}$ & $-6.4^{++}$ & $4.6^{+}$ & $11.1^{++}$ \\
\hline Davis Strait & & $-6.3^{++}$ & $-10.5^{++}$ & $8.2^{++}$ & $18.7^{++}$ \\
\hline North Atlantic & & $-10.7^{++}$ & $-16.4^{++}$ & $5.7^{++}$ & $22.1^{++}$ \\
\hline Greenland Sea & & $-6.1^{++}$ & $-6.8^{++}$ & $7.6^{++}$ & $14.4^{++}$ \\
\hline Lincoln Sea & & $-5.1^{++}$ & $-5.9^{++}$ & $6.8^{++}$ & $12.7^{++}$ \\
\hline
\end{tabular}

heat flux transferred to the atmosphere is small until the sea ice begins to break up and melt in the summer and moisture is released from the previously ice-covered ocean. Latent heat fluxes are directed into the atmosphere year-round in Davis Strait and Greenland Sea due to large areas of ice-free ocean that persists throughout the year.

Sensible heat flux is generally directed towards the surface for regions that are $100 \%$ sea ice covered during the cold season months (e.g., Baffin Bay and the Lincoln Sea) and then switches towards the atmosphere as the sea ice retreats in summer (Baffin Bay only). Regions that have large fractions of open-water year-round generally have a net sensible heat flux transfer towards the atmosphere year-round, though some exceptions occur. Greenland Sea and Davis Strait exhibit sensible heat flux to the atmosphere in early spring and late fall (October-December) when the ice-free ocean surface is much warmer than the overlying air; due to the higher heat capacity of water, the opposite is true for ice-covered regions.

A larger amount of sensible and latent heat flux tends to enter the atmosphere in the spring during early MO years in all regions. However, the Baffin Bay region is the only region with a majority of positive fluxes throughout the year. When melt happens early in Baffin Bay, the additional sensible and latent heat fluxes result in $\sim 14 \mathrm{~W} \mathrm{~m}^{-2}$ entering the atmosphere in spring (March-June) and $\sim 25 \mathrm{~W} \mathrm{~m}^{-2}$ in fall (September-December) due to a later FO. In contrast to Baffin Bay, turbulent flux anomalies in early MO years from Davis Strait and Lincoln Sea show no strong consistent pattern and switch between positive anomalies throughout the year. Compared to Baffin Bay, Davis Strait, which is further south, has larger latent heat fluxes entering the atmosphere between February and August during years with earlier MO, whereas sensible heat flux into the atmosphere is only larger during early MO years in February, April, and November, reflecting both early MO (April) and later FO (November). Over the Lincoln Sea there are no fluxes of heat or moisture into the atmosphere during the late fall, winter, and early spring due to the solid sea ice pack. However, by June there is an additional $\sim 12 \mathrm{~W} \mathrm{~m}^{-2}$ of turbulent flux energy transferred to the atmosphere during early melt years. This generates smaller turbulent fluxes in July due to warmer air temperatures than when melting has just begun in late MO years. The early MO year turbulent flux anomalies from Greenland Sea are different from the other three regions, as there is more heat and moisture entering the atmosphere in January, March, October, and December during early MO years.

Sensible and latent heat fluxes transfer heat and moisture into the local atmosphere and can cause the temperature and humidity to increase, which in turn should produce larger downwelling longwave flux at the surface due to the greenhouse feedback effect. Thus one would expect to see a larger net longwave flux (downwelling - upwelling) at the surface during early MO years when the local atmosphere contains more heat and moisture. We see evidence of this occurring until roughly July as there is more net longwave directed towards the surface of the ice sheet in most regions when the sea ice melts earlier (Fig. 8). In August the surface net longwave flux turns largely negative during early MO years, partly because the warmer ice sheet results in dominance of upwelling radiation fluxes, and partly because there is less of an influence of early season conditions.

The increase in heat and moisture into the atmosphere from the surrounding ocean in early $\mathrm{MO}$ versus late $\mathrm{MO}$ years and subsequent increase in energy at the ice sheet surface is shown in more detail for Baffin Bay in Fig. 9a and 

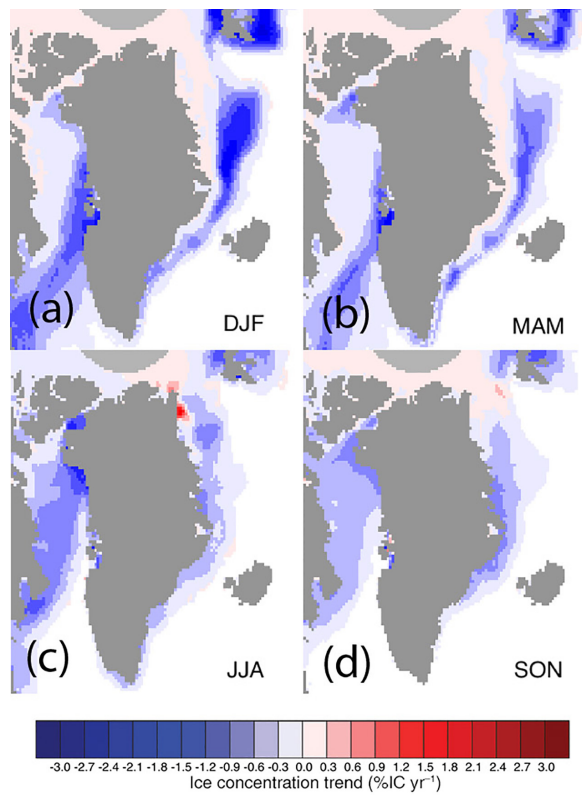

(e)
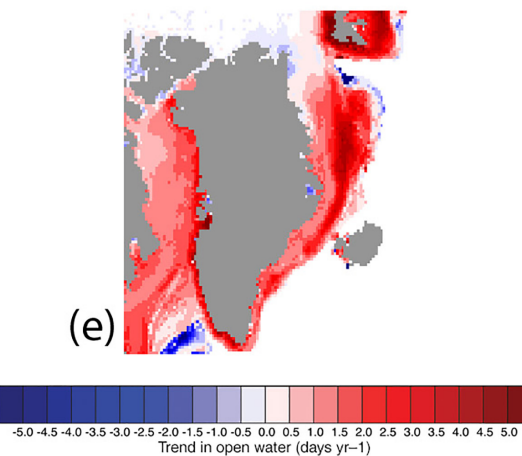

Figure 4. Seasonal trends in sea ice concentration from 1979 to 2015 (a-d) and number of ice-free days (e). Trends are computed using linear least squares and evaluated using Student's $t$ test at $95 \%$ confidence interval.

d. In April and May (day 1 to 61 in Fig. 9), there appears to be an out-of-phase relationship between latent heat flux over Baffin Bay and the specific humidity over the adjacent ice sheet, with pulses of moisture coming from the ocean surface being followed about a week later with rising specific humidity over the ice sheet. A similar pattern is observed between ocean sensible heat flux and near-surface air temperature over GrIS. In June and July (day 61 to 92), latent and sensible heat flux anomalies for early/late MO years fluctuate around zero, which suggests that these fluxes are similar between early and late MO years. In contrast, the specific humidity and temperature are higher in late MO years over the ice sheet in July (negative anomalies in Fig. 9a and d). This could be due to a roughly 1-month delay in late MO years compared to early $\mathrm{MO}$ for the sea ice, which causes increases in the temperatures and humidity later in the season (July) over the ice sheet. From the timing of early sea ice MO

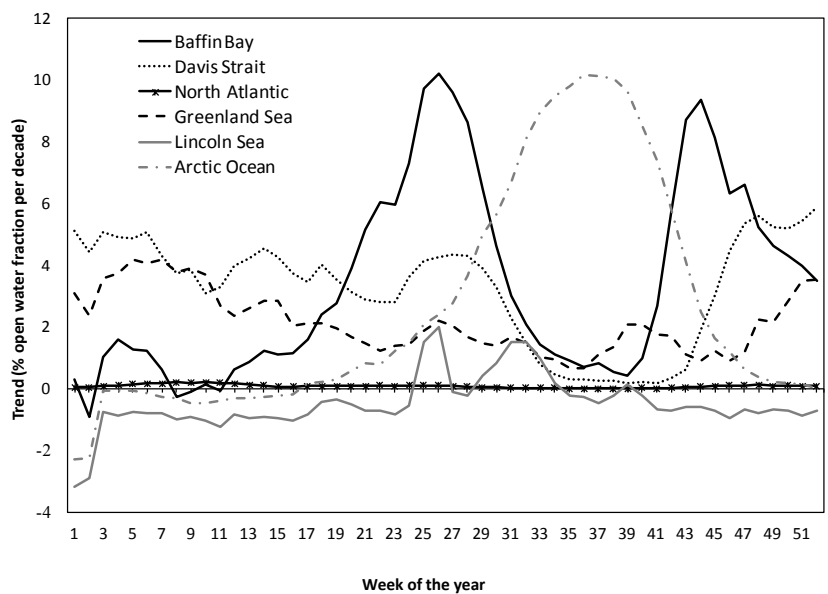

Figure 5. Trends in regional open-water fraction surrounding the Greenland ice sheet, computed from 1979 to 2014. Trends are computed using linear least squares.

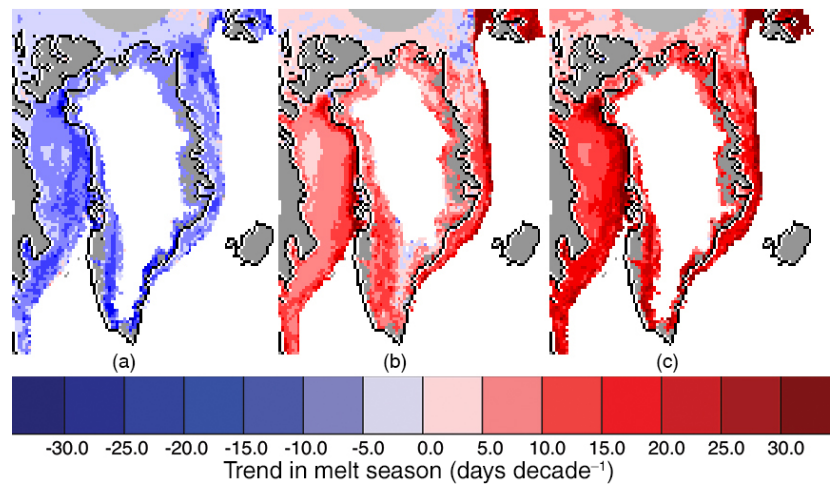

Figure 6. Trends in melt onset (a), freeze-up (b) and total melt season length (c) for sea ice and Greenland from 1979 to 2015. Trends are computed using linear least squares and evaluated at the $95 \%$ confidence level using Student's $t$ test.

(dotted blue line) to early GrIS MO (dotted blue, highlighted red line), large fluxes of moisture and heat released via the latent and sensible heat flux from the ice/ocean surface precede elevated humidity and temperature over the ice sheet.

One-week running lagged correlations between latent heat flux from the ocean and specific humidity over the ice sheet show large positive correlations during early MO years (Fig. 9b, solid blue lines), suggesting increased evaporation from earlier MO over sea ice may be driving the observed increase in specific humidity over the ice sheet 1 week later. A 1-week lag was chosen because sea ice and GrIS MO in Baffin Bay occur about 9 days apart on average, and also because water vapor in the troposphere has a residence time of about 2 weeks. These three highly correlated events precondition the ice sheet for earlier MO by increasing the specific humidity and thus the downwelling longwave flux earlier in the spring. In late MO years, the sea ice/ocean does also appear 

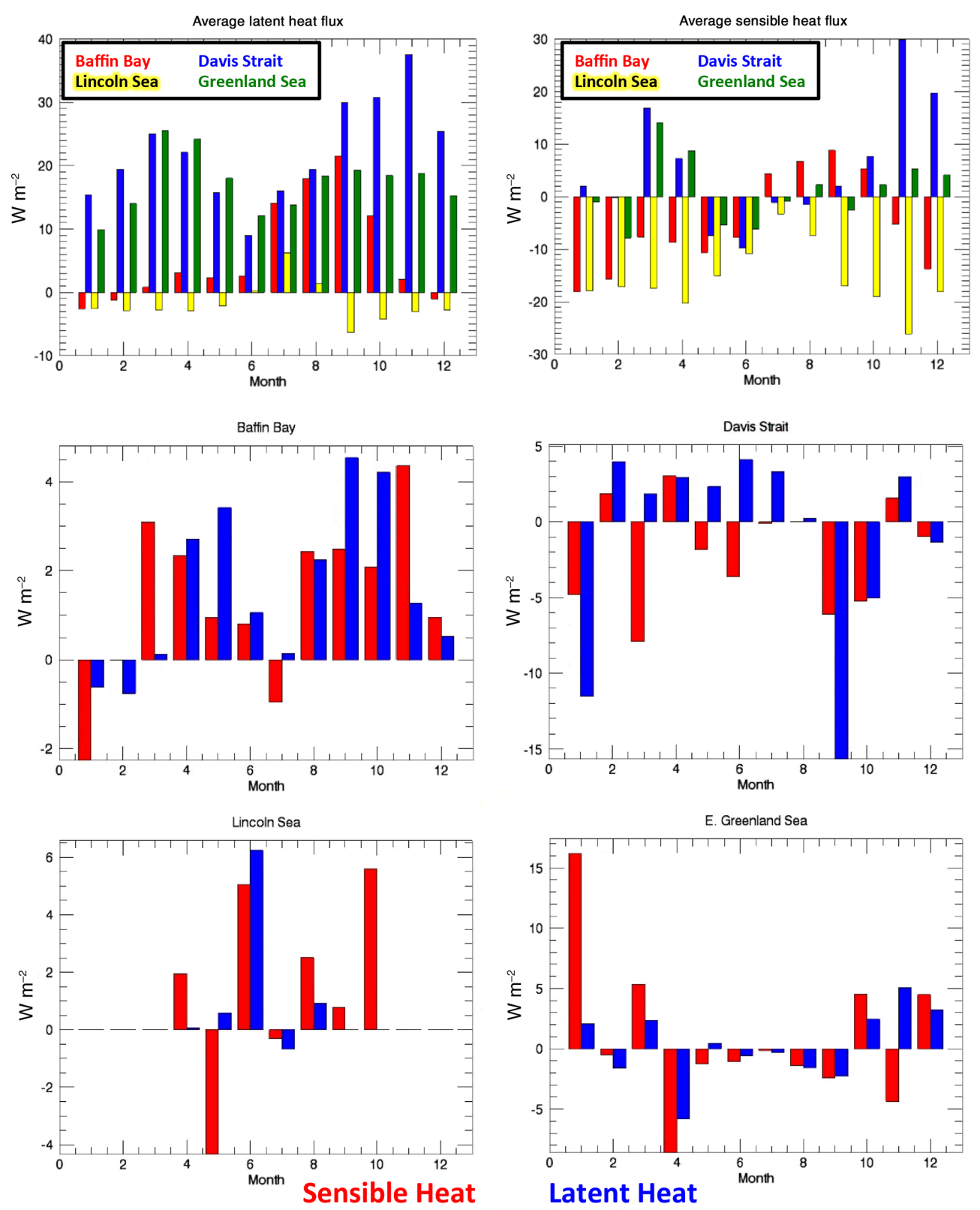

Figure 7. Top row graphs show the 2002 to 2015 average latent and sensible heat fluxes for each ocean region (denoted by color). The sign convention is such that positive fluxes are directed from the ocean to the atmosphere. Bottom two row graphs show the early minus late melt onset years for each region of the positive (into the atmosphere) sensible (red) and latent (blue) heat fluxes.

to play a small role in initiating $\mathrm{MO}$ on the ice sheet. Large amounts of latent heat are released from the surface in Baffin Bay at the timing of late MO, which in turn is correlated to increases in specific humidity over the ice sheet directly before MO, initiating melt (solid green lines). Since Baffin Bay MO is much later ( $\sim 1$ month) in late melt years, excess moisture into the atmosphere is delayed. Though because the environment is already warming seasonally, it does not require extra preconditioning for the melt to begin on GrIS compared to early melt years. This case is very similar to sensible heat flux released from Baffin Bay and ensuing temperature over the ice sheet (Fig. 9c). Comparing these 1-week lagged correlations to a zero-lag correlation (not shown), correlations for all variables in early and late MO years are highly negative, meaning they are out of phase (Fig. 9d).

Note also there are instances in April when both early and late melt years exhibit high correlations between either sensible or latent heat from the sea ice region and specific humidity or temperature over GrIS 1 week later. This may be related to opening of the North Water Polynya (Boisvert et al., 2012). As the open ocean is relatively warm compared to the overlying air in April, heat and moisture fluxes enter 


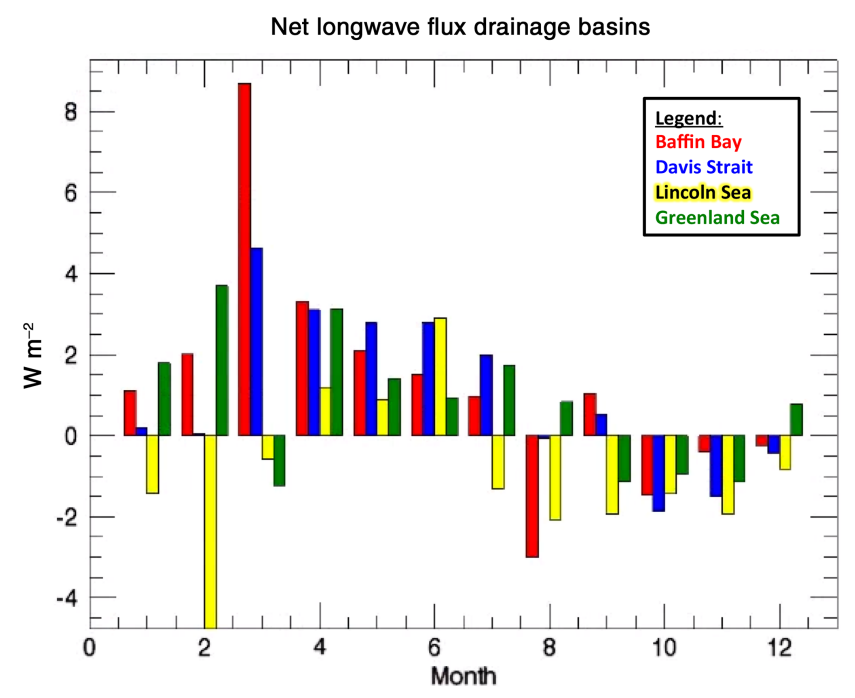

Figure 8. Net longwave flux (downwelling longwave flux - upwelling longwave flux) for early MO minus late MO years for the drainage basins of the Greenland ice sheet, where red bars are for Baffin Bay, blue bars are for Davis Strait, yellow bars are for Lincoln Sea, and green bars are for Greenland sea.

the atmosphere and are subsequently transferred over the ice sheet, increasing the specific humidity and air temperature.

In summary, sea ice in Baffin Bay/Davis Strait and the adjacent ice sheet surface conditions appear connected. MO and breakup of the sea ice triggers enhanced flux of heat and moisture into the atmosphere, which are observed over the ice sheet within a week. This results in a warming and moistening the local environment and preconditions the ice sheet for melt in early MO years. Therefore, when the MO of the sea ice is earlier, MO of GrIS is earlier and vice versa.

\subsection{Influence of large-scale atmospheric variability on Baffin Bay and Beaufort Sea}

The SVD analysis (4.1) indicated that both Baffin Bay/Davis Strait and the Beaufort Sea are regions with SIC and GrIS meltwater production covariability. In the case of Baffin Bay/Davis Strait, this was supported by the melt and turbulent heat flux analysis. Next we examine the influence of the large-scale atmospheric variability on this covariability using Pearson correlation and partial correlation.

In the Beaufort Sea, both $500 \mathrm{hPa}$ heights and SIC closely covary, particularly in June (Fig. 10a), in concert with high SIC covariance in this region with $\mathrm{EC}_{\mathrm{GrIS}}$ in the $\mathrm{HC}$ maps (Fig. 3). Here, the positive correlations between SIC and GrIS melt weaken significantly after June with almost no correlation by August (Table 3). The strong relationship between Beaufort SIC and GrIS melt in June is reduced considerably when the GBI is removed via partial correlation, as significant correlations remain only in southeast Greenland.
The correlation between SIC in Baffin Bay/Davis Strait and geopotential heights is relatively strong but not as extensive in June, while this signal mostly disappears in July and especially August (Fig. 10d; Table 3). This is associated with a weakening Baffin Bay SIC correlation with $\mathrm{EC}_{\mathrm{GrIS}}$ in the HC maps (Fig. 3a, e and i). Statistically significant correlations with meltwater production are focused on the west side of the ice sheet in June (Fig. 10e) but are minimal in July and August, when correlations over only 7 and $2 \%$ of the respective unmasked ice sheet area are statistically significant. Partial correlation analysis indicates that the GBI explains approximately two-thirds of this correlation in each month, though this still leaves the possibility that variations in Baffin Bay sea ice are in part responsible for the correlation with surface melt in western Greenland.

Because there is a potential local influence from Baffin Bay and Davis Strait, we next focus on GrIS melt only in west-central Greenland. The highest and lowest melt years in west-central Greenland (after removing trends) consistently correspond to patterns of anomalous SIC and geopotential heights in these years (Fig. 11). These variables show much less variation by month, though a weaker relationship appears particularly in the height field, which follows results from the SVD analysis (Fig. 11g-1). Additionally, a strong SIC pattern is evident not just in western Greenland but consistently on the east side of Greenland that is equally as strong (Fig. 11a-f). This suggests that the processes responsible for this signal expression to the west of Greenland probably also exist on a large enough scale to have an effect of similar strength on sea ice off Greenland's east coast - most likely a persistent ridge or trough, as suggested by the above results. By August, sea ice in Baffin Bay has melted in most years, but positive anomalies in SIC still appear in the lowest Greenland melt years (Fig. 11f).

In summary, the SVD analysis suggest covariability between SIC and GrIS melt in the Baffin Bay region (Fig. 3) that cannot fully be explained by large-scale atmospheric patterns (Figs. 10 and 11). Examination of a set of hypotheses applied for the entire GrIS and surrounding seas shows that trends and patterns in the Baffin and Davis Strait regions are consistent with local-scale influence (Table 4). In contrast, no other regions have evidence of covariability or trends and patterns consistent with local-scale influence.

\section{Discussion}

Sea ice and Greenland ice sheet melt demonstrate significant covariability during the summer, particularly June. While the majority of this relationship appears related to simultaneous atmospheric circulation forcing, analysis over Baffin Bay/Davis Strait and the adjacent ice sheet indicates that the covariability may additionally include a local-scale influence. This is in agreement with previous work by Rennermalm et al. (2009), who found the SIE and GrIS surface melt 

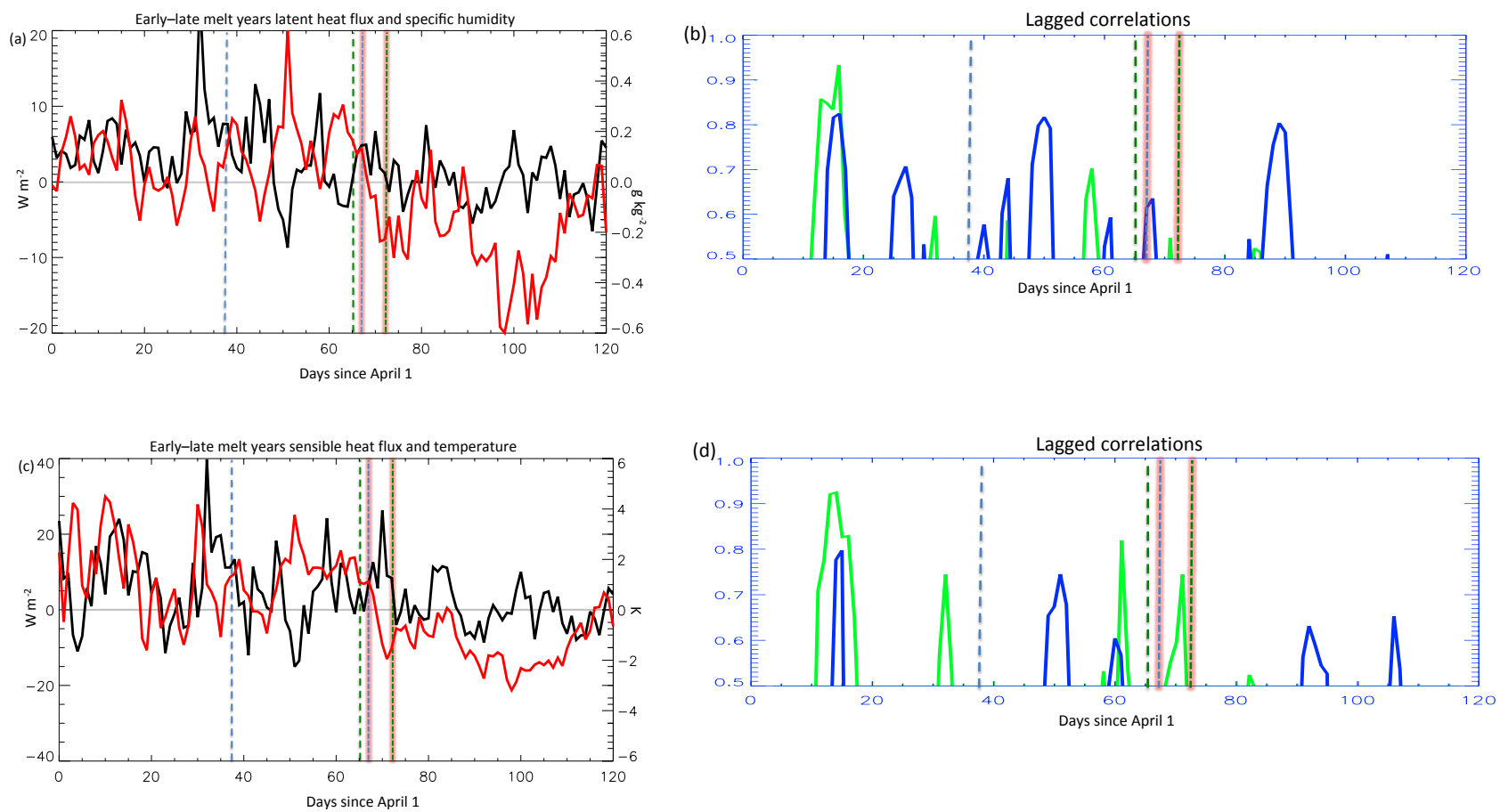

Figure 9. (a) Baffin Bay SIC region latent heat flux from early minus late MO years (black line) and Baffin Bay GrIS region specific humidity from early minus late MO years (red line). Dotted vertical lines represent the average early melt onset date for Baffin Bay (dotted blue), average late melt onset date for Baffin Bay (dotted blue, red highlight), average early melt onset date for GrIS (dotted green), and average late melt onset date for GrIS (dotted green, orange highlight). (b) One-week lagged running correlations (between 0.5 and 1.0$)$ for early melt years latent heat flux from Baffin Bay and specific humidity from GrIS (blue) and late melt onset latent heat flux from Baffin Bay and specific humidity from GrIS years (green). (c) Baffin Bay SIC region sensible heat flux from early minus late MO years (black line) and Baffin Bay GrIS region air temperature from early minus late MO years (red line). Dotted vertical lines represent the average early melt onset date for Baffin Bay (dotted blue), average late melt onset date for Baffin Bay (dotted green), average early melt onset date for GrIS (dotted blue, red highlight), and average late melt onset date for GrIS (dotted green, orange highlight). (d) One-week lagged running correlations (between 0.5 and 1.0) for early years sensible heat flux from Baffin Bay and air temperature from GrIS (blue) and late melt onset sensible heat flux from Baffin Bay and air temperature from GrIS years (green).

Table 3. Percentage of grid cells with a significant correlation at $\alpha=0.05$ relative to the total grid cells of the unmasked ice sheet. The Pearson's correlation is between ice sheet meltwater production and area-averaged sea ice concentration anomalies in the Beaufort Sea and Baffin Bay (hatched regions in Figs. 5a and 6a, respectively).

\begin{tabular}{lrr|rr}
\hline Month & \multicolumn{2}{c|}{ Beaufort Sea } & \multicolumn{2}{c}{ Baffin Bay } \\
\cline { 2 - 5 } & $\begin{array}{r}\text { Simple } \\
\text { correlation (\%) }\end{array}$ & $\begin{array}{r}\text { Partial } \\
\text { correlation (\%) }\end{array}$ & $\begin{array}{r}\text { Simple } \\
\text { correlation (\%) }\end{array}$ & $\begin{array}{r}\text { Partial } \\
\text { correlation (\%) }\end{array}$ \\
\hline June & 87.0 & 81.0 & 17.3 & 20.2 \\
July & 31.2 & 13.4 & 11.1 & 2.1 \\
August & 32.6 & 12.5 & 12.5 & 9.4 \\
\hline
\end{tabular}

extent to covary in the western part of the ice sheet, though the strongest relationships were found in August rather than June. Part of the discrepancy might be explained by the study period. This study extends through 2015 and includes years with larger anomalies in both SIC and GrIS melt. However, June is the time of year with the largest trends in OWF, reflecting earlier development of open water at a time when the atmosphere is still relatively cold. Thus, it is not surpris- ing that we find stronger covariability in June and a link with melt onset. An additional area of covariability in terms of melt onset timing is also seen in the Lincoln Sea sector.

While statistical analysis suggests a local-scale influence may be present on the western side of the ice sheet, the ability of the sea ice to influence GrIS melt depends on having anomalous heat and moisture sources that can travel to the ice sheet. In this study we find that turbulent fluxes are often 


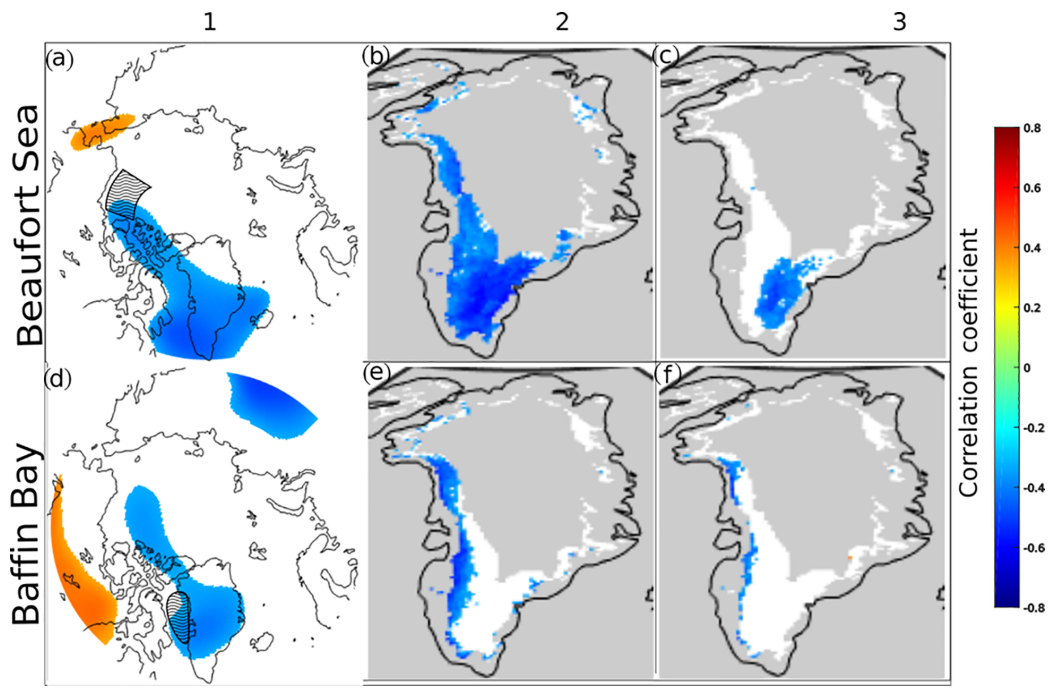

Figure 10. June correlation between spatially averaged SIC in the hatched region. Column (1) is $500 \mathrm{hPa}$ geopotential height field, Column (2) is Greenland meltwater production, and Column (3) is the same as Column (2) but with the effect of the Greenland Blocking Index removed (partial correlation). Correlation coefficients are not considered over the masked gray regions. All data are anomalies relative to 1979-2015 means with the least-squares trend line removed.
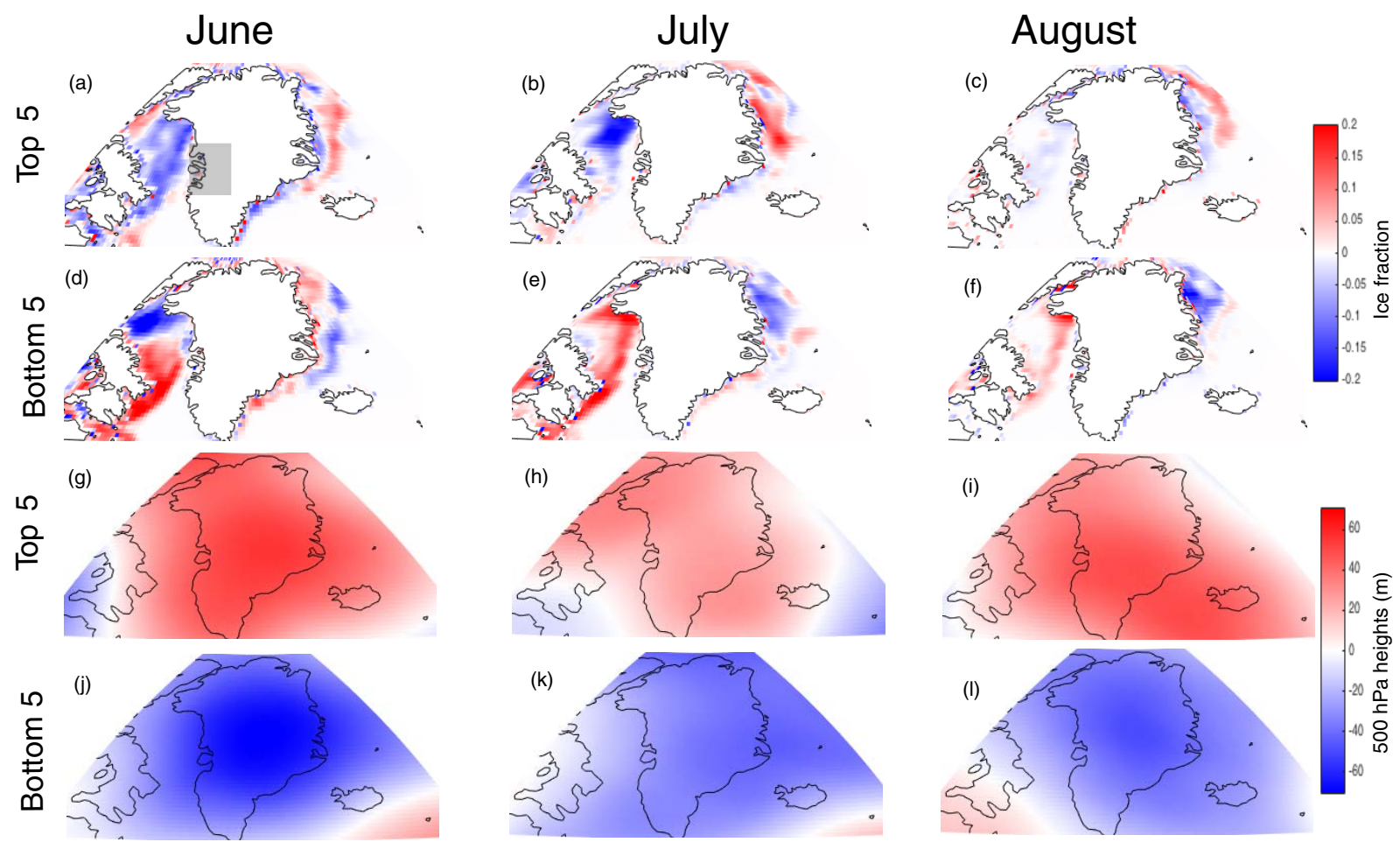

Figure 11. De-trended anomalies of SIC (a-f) and $500 \mathrm{hPa}$ geopotential heights $(\mathbf{g}-\mathbf{l})$ averaged over the 5 highest and lowest melt years in June, July, and August as indicated by de-trended meltwater production anomalies in the indicated gray region of the ice sheet. Units are ice fraction $(\mathbf{a}-\mathbf{f})$ and meters $(\mathbf{g}-\mathbf{l})$.

larger during early $\mathrm{MO}$ years in the spring and fall because areas where the ocean is ice free tends to be warmer than that of the air due to the higher heat capacity of water. Both latent and sensible heat fluxes are larger and more positive (from the ocean surface to the atmosphere) during early MO years, resulting in increased air temperature and specific humidity especially in May, when the atmosphere is $\sim 2 \mathrm{~K}$ warmer and $\sim 0.5 \mathrm{~g} \mathrm{~kg}^{-1}$ wetter. This excess heat and humidity increases 
(a)
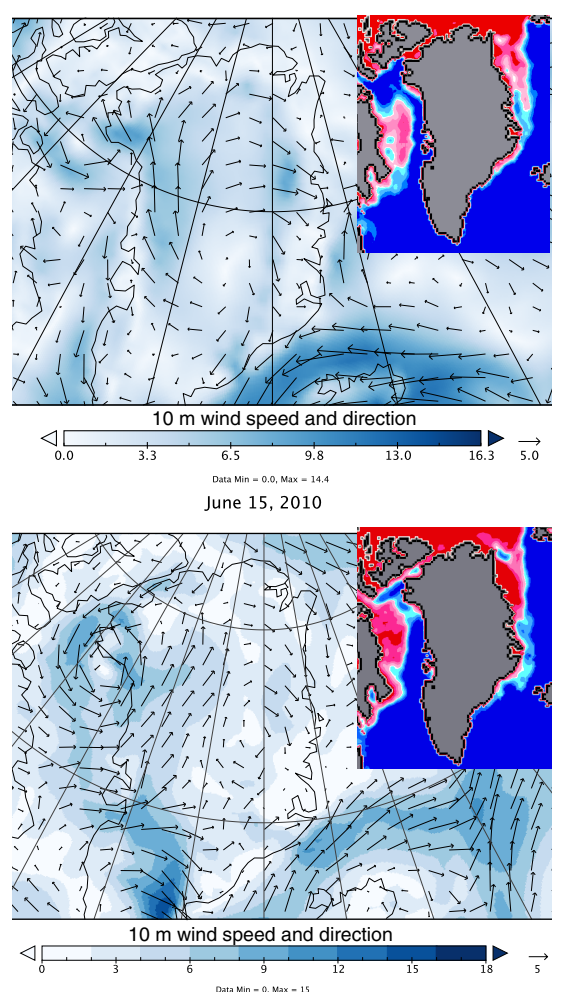

(b)

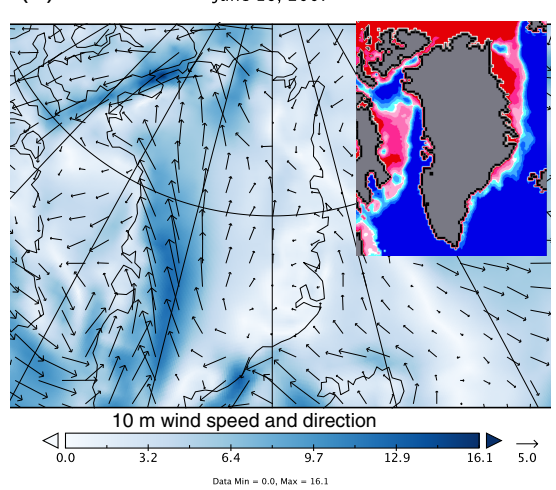

June 16,2015

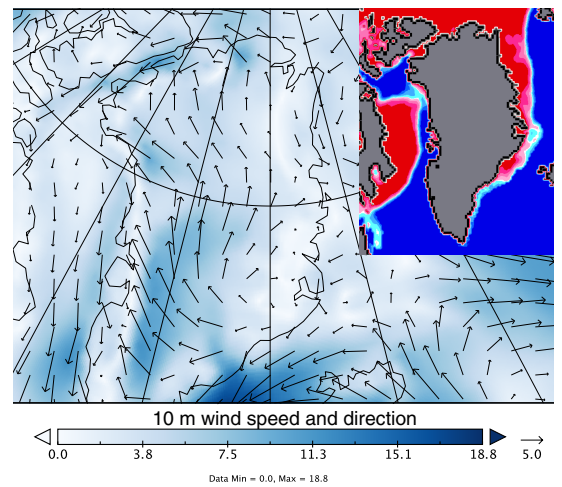

June 18, 2006
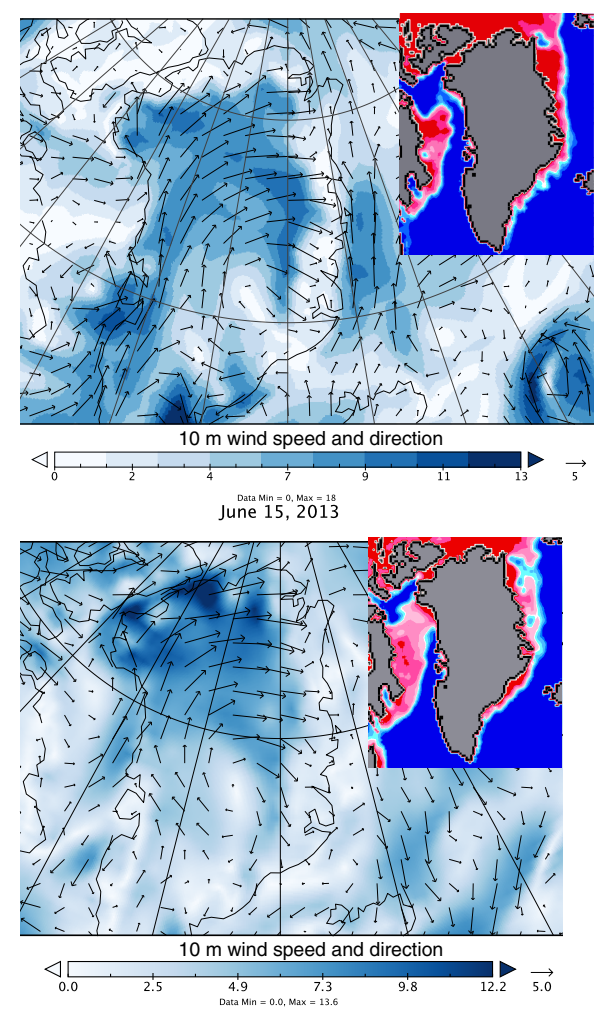

June 16, 2011
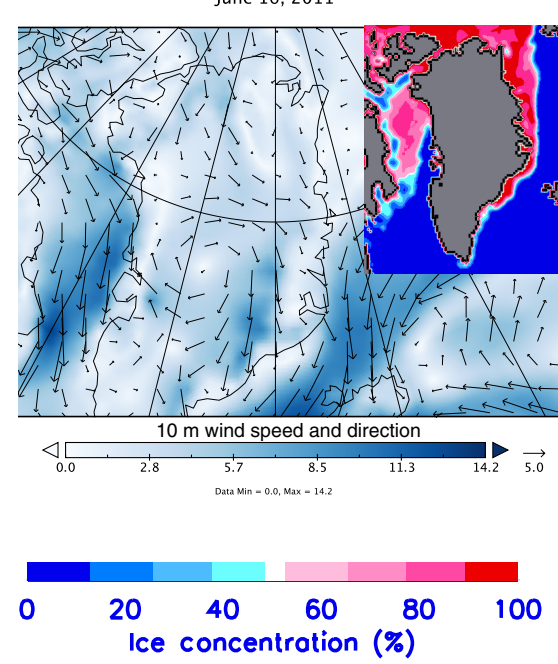

Figure 12. Wind vectors and speeds at $10 \mathrm{~m}$ from MERRA-2 during 4 early sea melt years over Baffin Bay (a) and 3 late sea melt years (b). Smaller figures superimposed on the wind maps show the sea ice concentration $(\%)$ for that day. 
Table 4. Summary table of results discussed in the main body of the paper.

\begin{tabular}{|c|c|c|c|c|c|}
\hline $\begin{array}{l}\text { Analysis } \\
\text { performed }\end{array}$ & $\begin{array}{l}\text { Davis } \\
\text { Strait }\end{array}$ & $\begin{array}{l}\text { Baffin } \\
\text { Bay }\end{array}$ & $\begin{array}{l}\text { Lincoln } \\
\text { Sea }\end{array}$ & $\begin{array}{l}\text { Greenland } \\
\text { Sea }\end{array}$ & $\begin{array}{l}\text { North } \\
\text { Atlantic }\end{array}$ \\
\hline $\begin{array}{l}\text { SVD: GrIS } \\
<>\text { SIC } \\
\text { (Fig. 3) }\end{array}$ & & June & & & \\
\hline $\begin{array}{l}\text { SIC trends } \\
\text { (Fig. 4) }\end{array}$ & $\begin{array}{l}\text { Reduced in } \\
\text { all seasons }\end{array}$ & $\begin{array}{l}\text { Reduced in } \\
\text { all seasons }\end{array}$ & No change & $\begin{array}{l}\text { Positive near } \\
\text { the coast in } \\
\text { spring and winter }\end{array}$ & N/A \\
\hline $\begin{array}{l}\text { Open water } \\
\text { days (Fig. 4) }\end{array}$ & Increase & Increase & Increase & Increase & Increase \\
\hline $\begin{array}{l}\text { OWF trends } \\
\text { (Fig. 5) }\end{array}$ & $\begin{array}{l}\text { Positive } \\
\text { throughout } \\
\text { shoulder } \\
\text { seasons }\end{array}$ & $\begin{array}{l}\text { Sharp peak } \\
\text { in June } \\
\text { and } \\
\text { October }\end{array}$ & Mixed & $\begin{array}{l}\text { Positive } \\
\text { throughout } \\
\text { year, no } \\
\text { sharp peaks }\end{array}$ & N/A \\
\hline $\begin{array}{l}\text { Relative start } \\
\text { of melt on } \\
\text { SIC and GrIS } \\
\text { (Table 2) }\end{array}$ & $\begin{array}{l}\text { SIC MO earlier, } \\
\text { SIC FO later }\end{array}$ & $\begin{array}{l}\text { SIC MO earlier, } \\
\text { SIC FO later }\end{array}$ & $\begin{array}{l}\text { SIC and GrIS } \\
\text { similar }\end{array}$ & $\begin{array}{l}\text { SIC MO earlier, } \\
\text { SIC FO later }\end{array}$ & N/A \\
\hline $\begin{array}{l}\text { Trends in } \\
\text { timing of } \\
\text { EMO, MO, } \\
\text { FO (Table 2, } \\
\text { Fig. 6) }\end{array}$ & $\begin{array}{l}\text { MO earlier } \\
\text { FO later }\end{array}$ & $\begin{array}{l}\text { MO earlier } \\
\text { FO later }\end{array}$ & $\begin{array}{l}\text { MO earlier } \\
\text { FO later }\end{array}$ & $\begin{array}{l}\text { MO earlier } \\
\text { FO later }\end{array}$ & N/A \\
\hline $\begin{array}{l}\text { Synchronicity } \\
\text { between GrIS } \\
\text { and SIC } \\
\text { EMO, MO, FO } \\
\text { time series }\end{array}$ & & $\begin{array}{l}R>0.6 \text { for } \mathrm{MO}, \\
\mathrm{FO} \\
R>0.5 \\
\text { for detrended } \\
\text { data }\end{array}$ & $\begin{array}{l}R>0.6 \text { for } \\
\mathrm{MO}, \mathrm{FO} \\
R>0.5 \\
\text { for detrended } \\
\text { data }\end{array}$ & $\begin{array}{l}R>0.5 \\
\text { for EMO }\end{array}$ & \\
\hline $\begin{array}{l}\text { Latent heat } \\
\text { fluxes (Fig. 7) }\end{array}$ & $\begin{array}{l}\text { positive } \\
\text { all year }\end{array}$ & $\begin{array}{l}\text { Positive } \\
\text { all year }\end{array}$ & $\begin{array}{l}\text { Positive } \\
\text { in summer }\end{array}$ & $\begin{array}{l}\text { Positive } \\
\text { all year }\end{array}$ & N/A \\
\hline $\begin{array}{l}\text { Sensible heat } \\
\text { fluxes (Fig. 7) }\end{array}$ & $\begin{array}{l}\text { Positive } \\
\text { spring/fall }\end{array}$ & $\begin{array}{l}\text { Positive } \\
\text { JASO }\end{array}$ & $\begin{array}{l}\text { Negative } \\
\text { all year }\end{array}$ & $\begin{array}{l}\text { Positive } \\
\text { spring/fall }\end{array}$ & N/A \\
\hline $\begin{array}{l}\text { Early/late } \\
\text { MO years } \\
\text { composites (Fig. 7) }\end{array}$ & $\begin{array}{l}\text { Positive in } \\
\text { winter, negative } \\
\text { rest of year }\end{array}$ & $\begin{array}{l}\text { Majority of } \\
\text { positive } \\
\text { anomalies }\end{array}$ & Mixed & Mixed & \\
\hline $\begin{array}{l}\text { Net longwave } \\
\text { fluxes (Fig. 8) }\end{array}$ & $\begin{array}{l}\text { Positive } \\
\text { anomalies } \\
\text { in spring }\end{array}$ & $\begin{array}{l}\text { Positive } \\
\text { anomalies } \\
\text { in spring }\end{array}$ & $\begin{array}{l}\text { Positive } \\
\text { anomalies } \\
\text { in spring }\end{array}$ & $\begin{array}{l}\text { Positive } \\
\text { anomalies } \\
\text { in spring }\end{array}$ & N/A \\
\hline
\end{tabular}

downwelling fluxes to the ice sheet earlier in the year, preconditioning the ice sheet and triggering melt (also shown in Fig. 8). For late MO years, this phenomenon occurs later in the season, and this is most likely why we see larger fluxes during late MO years in the summer months (i.e., July depending on the climatology of the region). This is specifically true for Baffin Bay, where throughout the winter months the region is completely covered by sea ice, creating a barrier between ocean-atmosphere energy exchanges. This is also valid for the Lincoln Sea in the content of melt ponds and a higher occurrence of leads forming on the thick multi-year ice during the summer months.

Turbulent fluxes from increased open water can reach well above the boundary layer (e.g., Yulaeva et al., 2001), but this depends on the frequency of spring and early summer inversions that cap the atmospheric boundary layer. Furthermore, if katabatic winds are persistent at the ice edge, this will keep onshore flow from reaching the ice sheet (Noël et al., 2014), though a possibility remains for mixing in the boundary layer via a barrier wind mechanism (van den Broeke and Gallée, 
1996). Analysis of daily winds around the timing of sea ice melt shows that during early MO years over the sea ice, wind direction is from the open-water areas of Baffin Bay onto the GrIS, which helps support our claims that earlier melt onset in part drives early melt over Greenland (Fig. 12). In late MO years, the wind direction is reversed.

Finally, we note that SVD analysis reveals the strongest relationship between GrIS melt and sea ice variability occurs within the Beaufort Sea. This appears to be related to the positioning of a ridge near Greenland that enhances both ice sheet melt and sea ice retreat as stronger easterlies help to circulate ice west out of the Beaufort Sea. SVD analysis shows the covariability in June is reduced considerably when the GBI is removed via partial correlation, evidenced by the large reduction in percentage of grid cells with a significant correlation (not shown). This mechanism has been identified previously as a way to transport and melt ice between the Beaufort Sea and the East Siberian Sea (Rogers, 1978; Maslanik et al., 1999). We speculate that no mechanism originating from sea ice variability directly influences GrIS melt from a distance of hundreds of kilometers away, though Liu et al. (2016) argue that sea ice loss within the central Arctic has favored stronger and more frequent blocking events over Greenland.

In 2012, as the sea ice cover reached its all-time record low September extent, the Greenland ice sheet also experienced a record amount of surface melt and ice mass loss (Tedesco et al., 2013). Several explanations have been put forth to explain this anomalous melt, including increased downwelling longwave radiation from low-level liquid clouds (Bennartz et al., 2013), advection of moist warm air over Greenland (Neff et al., 2014), and dominance of non-radiative fluxes (Fausto et al., 2016). While this event was likely a result of atmospheric circulation patterns that transported warm, humid air over the southern and western part of the ice sheet, the sea ice melt season began a week earlier than the 1981-2010 longterm mean over Davis Strait and 3 days earlier over Baffin Bay. This earlier melt onset of the sea ice may have provided an additional source of warm, moist air over the adjacent ice sheet.

\section{Conclusions}

Based on multiple lines of statistical evidence, we identified western Greenland as a region where direct influence from sea ice on the GrIS SMB is possible. SVD analysis revealed that extreme melt years over the adjacent ice sheet are accompanied by strong SIC anomalies within Baffin Bay and Davis Strait that would be expected if a local-scale thermodynamic influence were occurring. This is true even after near-surface temperature and climate index influences are removed.

The covariance is strongest in June, which may be partially due to the lower variability in interannual June meltwater production over the entire ice sheet relative to the rest of summer, with a standard deviation simulated by MAR of $0.84 \mathrm{~mm}$ water equivalent $\mathrm{day}^{-1}$ compared to $0.95 \mathrm{in} \mathrm{Au}-$ gust and 1.12 in July. Additionally, June variability in sea ice may have a greater potential to influence GrIS melt given that the ice sheet is transitioning into its warm season regime and reaching the freezing point for the first time in many locations. This is further confirmed through correlations between the timing of melt onset, which occurs on average 9 days earlier over the sea ice than on the adjacent ice sheet and in turn allows for earlier development of open water and enhanced transfer of turbulent heat fluxes from the ocean to the atmosphere. More heat and moisture is transported to the local atmosphere from the ice-free ocean surface via turbulent fluxes in years when sea ice melts earlier. Daily wind field analysis suggests these enhanced turbulent fluxes are transferred to the ice sheet, allowing the local atmosphere over the GrIS to warm and become more humid, which in turn impacts the net downwelling longwave flux, helping precondition the surface for earlier melt onset.

However, despite evidence of a possible local-scale influence, all analysis incorporating $500 \mathrm{hPa}$ height anomalies suggests that the large-scale atmospheric circulation remains the primary melt driver in this part of the ice sheet and for the ice sheet as a whole. Anomalous atmospheric circulation features include increased frequency of the negative phase of the Arctic Dipole (Overland and Wang, 2010) and a persistently negative summer North Atlantic Oscillation (van Angelen et al., 2013). Continued Arctic amplification and associated shifts in Arctic atmospheric circulation and their persistence will theoretically continue to enhance warming in the vicinity of Greenland (Francis and Vavrus, 2012, 2015). Nevertheless, our study suggests a local response is also possible and, as the sea ice cover continues to retreat around the Greenland ice sheet, this should present further opportunities for local enhancement of summer ice sheet melt.

Data availability. AIRS data are freely available at www.airs.jpl. nasa.gov and MERRA-2 data can be found at gmao.gsfc.nasa.gov. The sea ice concentration data are available from the national snow and ice data center (nsidc.org).

Competing interests. The authors declare that they have no conflict of interest.

Acknowledgements. This work was funded by the National Science Foundation PLR 1304807. All data used in this study were obtained from free and open data repositories. Detailed information is provided in the methods section. The work of Linette Boisvert was funded by NASA ROSES 2012 IDS proposal no. 12-IDS12-0120.

Edited by: Edward Hanna

Reviewed by: two anonymous referees 


\section{References}

Alexander, P. M., Tedesco, M., Fettweis, X., van de Wal, R. S. W., Smeets, C. J. P. P., and van den Broeke, M. R.: Assessing spatiotemporal variability and trends in modelled and measured Greenland Ice Sheet albedo (2000-2013), The Cryosphere, 8, 2293 2312, https://doi.org/10.5194/tc-8-2293-2014, 2014.

Ballinger, T. J., Hanna, E., Hall, R. J., and Hoyer, J. L.: Greenland coastal air temperatures linked to Baffin Bay and Greenland ice conditions during autumn through regional blocking patterns, Clim. Dyn., https://doi.org/10.1007/s00382-017-3583-3, 2017.

Bennartz, R., Shupe, M. D., Turner, D. D., Walden, V. P., Steffen, K., Cox, C. J., Kullie, M. S., Miller, N. B., and Pettersen, C.: July 2012 Greenland melt extent enhanced by low-level liquid clouds, Nature, 496, 83-86, https://doi.org/10.1038/nature12002, 2013.

Bezeau, P., Sharp, M., and Gascon, G.: Variability in summer anticyclonic circulation over the Canadian Arctic Archipelago and west Greenland in the late 20th/early 21 st centuries and its effect on glacier mass balance, Int. J. Climatol., 35, 540-557, https://doi.org/10.1002/joc.4000, 2015.

Bhatt, U. S., Walker, D. A., Raynolds, M. K., Comiso, J. C., Epstein, H. E., Jia, G., Gens, R., Pinzon, J. E., Tucker, C. J., Tweedie, C. E., and Webber, P. J.: Circumpolar Arctic Tundra Vegetation Change Is Linked to Sea Ice Decline, Earth Interact., 14, 1-20, https://doi.org/10.1175/2010EI315.1, 2010.

Boisvert, L. N., Markus, T., Parkinson, C. L., and Vihma, T.: Moisture fluxes derived from EOS Aqua satellite data for the North Water polynya over 2003-2009, J. Geophys. Res., 117, D06119, https://doi.org/10.1029/2011JD016949, 2012.

Boisvert, L. N. and Stroeve, J. C.: The Arctic is becoming warmer and wetter as revealed by the Atmospheric Infrared Sounder, Geophys. Res. Lett., 42, 4439-4446, https://doi.org/10.1002/2015GL063775, 2015.

Boisvert, L. N., Wu, D. L., and Shie, C.-L.: Increasing evaporation amounts seen in the Arctic between 2003-2013 from AIRS data, J. Geophys. Res.-Atmos., 120, 6865-6881, https://doi.org/10.1002/2015JD023258, 2015.

Boisvert, L. N., Petty, A. A., and Stroeve, J. C.: The Impact of the Extreme Winter 2015/16 Arctic Cyclone on the Barents-Kara Seas, Mon. Weather Rev., 144, 4279-4287, https://doi.org/10.1175/MWR-D-16-0234.1, 2016.

Bosilovich, M. G., Robertson, F. R., and Chen, J.: Global Energy and Water Budgets in MERRA, J. Climate, 24, 5721-5739, https://doi.org/10.1175/2011JCLI4175.1, 2011.

Bretherton, C. S., Smith, C., and Wallace, J. M.: An intercomparison of methods for finding coupled patterns in climate data, J. Climate, 5, 451-560, 1992.

Brun, E., David, P., Sudul, M., and Brunot, G.: A numerical model to simulate snow-cover stratigraphy for operational avalanche forecasting, J. Glaciol., 38, 13-22, 1992.

Cassano, E. N., Cassano, J. J., Higgins, M. E., and Serreze, M. C.: Atmospheric impacts of an Arctic sea ice minimum as seen in the Community Atmosphere Model, Int. J. Climatol., 34, 766-779, https://doi.org/10.1002/joc.3723, 2014.

Cavalieri, D., Parkinson, C., Gloersen, P., and Zwally, H. J.: Sea Ice Concentrations from Nimbus-7 SMMR and DMSP SSM/I Passive Microwave Data, (1979-2013), Boulder, Colorado USA, National Snow and Ice Data Center, Digital media, 1996.
Cohen, J., Cohen, P., West, S. G., and Aiken, L. S.: Applied multiple regression/correlation analysis for the behavioral sciences (3 Edn.), Routledge, Mahwah, 2003.

Comiso, J. C.: Correlation and trend studies of the sea-ice cover and surface temperatures in the Arctic, Ann. Glaciol., 34, 420-428, 2002.

Cullather, R. I. and Bosilovich, M. G.: The Energy Budget of the Polar Atmosphere in MERRA, J. Climate, 25, 5-24, https://doi.org/10.1175/2011JCLI4138.1, 2011a.

Cullather, R. I. and Bosilovich, M. G.: The Moisture Budget of the Polar Atmosphere in MERRA, J. Climate, 24, 2861-2879, https://doi.org/10.1175/2010JCLI4090.1, 2011 b.

Dee, D. P. and Uppala, S.: Variational bias correlation of satellite radiance data in the ERA-Interim reaqnalysis, Q. J. R. Meteorol. Soc., 135, 1830-1841, https://doi.org/10.1002/qj.493, 2009.

De Ridder, K. and Gallée, H.: Land surface-induced regional climate change in southern Israel, J. Appl. Meteorol., 37, 14701485, 1998.

Deser, C., Walsh, J. E., and Timlin, M. S.: Arctic Sea Ice Variability in the Context of Recent Atmospheric Circulation Trends, J. Climate, 13, 617-633, 2000.

Doyle, S. H., Hubbard, A., van de Wal, R. S. W., Box, J. E., van As, D., Scharrer, K., Meierbachtol, T. W., Smeets, P. C. J. P., Harper, J. T., Johansson, E., Mottram, R. H., Mikkelsen, A. B., Wilhelms, F., Patton, H., Christoffersen, P., and Hubbard, B.: Amplified melt and flow of the Greenland ice sheet driven by late-summer cyclonic rainfall, Nat. Geosci., 8, 647653, https://doi.org/10.1038/ngeo2482, 2015.

Enderlin, E. M., Howat, I. M., Jeong, S., Noh, M.-J., van Angelen, J. H., and van den Broeke, M. R.: An improved mass budget for the Greenland ice sheet, Geophys. Res. Lett., 41, 866-872, https://doi.org/10.1002/2013GL059010, 2014.

Fang, Z.-F: Statistical relationship between the northern hemisphere sea ice and atmospheric circulation during wintertime, in: Observation, Theory and Modeling of Atmospheric Variability, World Scientific Series on Meteorology of East Asia, edited by: Zhu, X, World Scientific, 2004.

Fausto, R. S., van As, D., Box, J. E., Colgan, W., Langen, P. L., and Mottram, R. H.: The implication of nonradiative energy fluxes dominating Greenland ice sheet exceptional ablation area surface melt in 2012, Geophys. Res. Lett., 43, 2649-2658, https://doi.org/10.1002/2016GL067720, 2016.

Fettweis, X., Gallée, H., Lefebre, F., and van Ypersele, J.-P.: Greenland surface mass balance simulated by a regional climate model and comparison with satellite-derived data in 1990-1991, Clim. Dyn., 24, 623-640. https://doi.org/10.1007/s00382-005-0010-y, 2005.

Fettweis, X., Tedesco, M., van den Broeke, M., and Ettema, J.: Melting trends over the Greenland ice sheet (1958-2009) from spaceborne microwave data and regional climate models, The Cryosphere, 5, 359-375, https://doi.org/10.5194/tc-5-359-2011, 2011.

Francis, J. A. and Vavrus, S. J.: Evidence linking Arctic amplification to extreme weather in mid-latitudes, Geophys. Res. Lett., 39, L06801, https://doi.org/10.1029/2012GL051000, 2012.

Francis, J. A., Chan, W., Leathers, D. J., Miller, J. R., and Veron, D. E.: Winter Northern Hemisphere weather patterns remember summer Arctic sea-ice extent, Geophys. Res. Lett., 36, L07503, https://doi.org/10.1029/2009GL037274, 2009. 
Fyke, J. G., Vizcaino, M., Lipscomb, W., and Price, S.: Future climate warming increases Greenland ice sheet surface mass balance variability, Geophys. Res. Lett., 41, 470-475, https://doi.org/10.1002/2013GL058172, 2014a.

Fyke, J. G., Vizcaino, M., and Lipscomb, W. H.: The pattern of anthropogenic signal emergence in Greenland Ice Sheet surface mass balance, Geophys. Res. Lett., 41, 6002-6008, https://doi.org/10.1002/2014GL060735, 2014b.

Gallée, H. and Schayes, G.: Development of a three-dimensional meso- $\gamma$ primitive equation model - katabatic winds simulation in the area of Terra-Nova Bay, Antarctica, Mon. Weather Rev., 122, 671-685, 1994.

Gallée, H., Peyaud V., and Goodwin, I.: Simulation of the net snow accumulation along the Wilkes Land transect, Antarctica, with a regional climate model, Ann. Glaciol., 41, 17-22, 2005.

Ghatak, D., Frei, A., Gong, G., Stroeve, J., and Robinson, D.: On the emergence of an Arctic amplification signal in terrestrial Arctic snow extent, J. Geophys. Res., 115, D24105, https://doi.org/10.1029/2010JD014007, 2010.

Hanna, E., Fettweis, X., Mernild, S. H., Cappelen, J., Ribergaard, M. H., Shuman, C. A., Steffen, K., Wood, L., and Mote, T. L.: Atmospheric and oceanic climate forcing of the exceptional Greenland ice sheet surface melt in summer 2012, Int. J. Climatol., 34, 1022-1037, https://doi.org/10.1002/joc.3743, 2013.

Hanna, E., Huybrechts, P., Steffen, K., Cappelen, J., Huff, R., Shuman, C., Irvine-Fynn, T., Wise, S., and Griffiths, M.: Increased runoff from melt from the Greenland ice sheet: A response to global warming, J. Climate, 21, 331-341, https://doi.org/10.1175/2007JCLI1964.1, 2008.

Hanna, E., Jonsson, T., and Box, J. E.: An analysis of Icelandic climate since the nineteenth Century, Int. J. Climatol, 24, 1193 1210, doi.10.1002/joc.1051, 2004.

Kay, J. E., Raeder, K., Gettelman, A., and Anderson, J.: The Boundary Layer Response to Recent Arctic Sea Ice Loss and Implications for High-Latitude Climate Feedbacks, J. Climate, 24, 428447, https://doi.org/10.1175/2010JCLI3651.1, 2011.

Lefebre, F., Gallée, H., van Ypersele, J. P., and Greuell, W.: Modeling of snow and ice melt at ETH-Camp (West Greenland): A study of surface albedo, J. Geophys. Res., 108, 4231, https://doi.org/10.1029/2001JD001160, 2003.

Lefebre, F., Fettweis, X., Galée, H., van Ypersele, J.-P., Marbaix, P., Greuell, W., and Calanca, P.: Evaluation of a high-resolution regional climate simulation over Greenland, Clim. Dynam, 25, 99-116. https://doi.org/10.1007/s00382-005-0005-8, 2005.

Lindsay, R., Wensnahan, M., Schweiger, A., and Zhang, J.: Evaluation of Seven Different Atmospheric Reanalysis Products in the Arctic, J. Climate, 27, 2588-2606, https://doi.org/10.1175/JCLID-13-00014.1, 2014

Liu, J., Chen, Z.,1 Francis, J., Song, M., Mote, T., and Hu, Y.: Has Arctic Sea Ice Loss Contributed to Increased Surface Melting of the Greenland Ice Sheet?, J. Climate, 29, 3373-3386, https://doi.org/10.1175/JCLI-D-15-0391.1, 2016.

Markus, T., Stroeve, J. C., and Miller, J.: Recent changes in Arctic sea ice melt onset, freezeup and melt season length, J. Geophys. Res., 114, C12024, https://doi.org/10.1029/2009JC005436, 2009

Mattingly, K. S., Ramseyer, C. A., Rosen, J. J., Mote, T. L., and Muthyala, R.: Increasing water vapor transport to the Greenland Ice Sheet revealed using self-organizing maps, Geophys. Res.
Lett., 43, 9250-9258, https://doi.org/10.1002/2016GL070424, 2016.

Mioduszewski, J. R., Rennermalm, A. K., Hammann, A., Tedesco, M., Noble, E. U., Stroeve, J. C., and Mote, T. L.: Atmospheric drivers of Greenland surface melt revealed by selforganizing maps, J. Geophys. Res.-Atmos., 121, 5095-5114, https://doi.org/10.1002/2015JD024550, 2016

Mortin, J., Svensson, G., Graverson, R., Kapsch, M.-L., Stroeve, J. C., and Boisvert, L. N.: Melt onset over Arctic sea ice controlled by atmospheric moisture transport, Geophys. Res. Lett. 43, 6636-6642, https://doi.org/10.1002/2016GL069330, 2016.

Mote, T. L.: MEaSUREs Greenland Surface Melt Daily $25 \mathrm{~km}$ EASE-Grid 2.0, (indicate subset used), Boulder, Colorado USA: NASA DAAC at the National Snow and Ice Data Center, https://doi.org/10.5067/MEASURES/CRYOSPHERE/nsidc0533.001, 2014.

Mote, T. L.: Greenland surface melt trends 1973-2007: Evidence of a large increase in 2007, Geophys. Res. Lett., 34, L22507, https://doi.org/10.1029/2007GL031976, 2007.

Neff, W., Compo, G., Ralph, F. M., and Shupe, M. D.: Continental heat anomalies and the extreme melting of the Greenland ice surface in 2012 and 1889, J. Geophys. Res.-Atmos., 119, 65206536, https://doi.org/10.1002/2014JD021470, 2014.

Noël, B., Fettweis, X., van de Berg, W. J., van den Broeke, M. R., and Erpicum, M.: Sensitivity of Greenland Ice Sheet surface mass balance to perturbations in sea surface temperature and sea ice cover: a study with the regional climate model MAR, Cryosph., 8, 1871-1883, https://doi.org/10.5194/tc-81871-2014, 2014.

Notz, D. and Stroeve, J.: Observed Arctic sea-ice loss directly follows anthropogenic $\mathrm{CO}_{2}$ emission, Science, https://doi.org/10.1126/science.aag2345, 2016.

Ornaheim, I. H., Eldevik, T., Arthun, M., Ingvaldsen, R. B., and Smedsrud, L. H.: Skillful prediction of Barents Sea ice cover, Geophys. Res. Lett., 42, 5364-5371, https://doi.org/10.1002/2015GL064359, 2016.

Overland, J. E. and Wang, M.: Large-scale atmospheric circulation changes are associated with the recent loss of Arctic sea ice, Tellus A, 62, 1-9, https://doi.org/10.1111/j.16000870.2009.00421.x, 2010.

Parkinson, C.: Spatially mapped reductions in the length of the Arctic sea ice season, Geophys. Res. Lett., 41, 4316-4322, https://doi.org/10.1002/2014GL060434, 2014.

Polyakov, I. V., Walsh, J. E., and Kwok, R.: Recent Changes of Arctic Multiyear Sea Ice Coverage and the Likely Causes, B. Am Meteorol. Soc., 93, 145-151, https://doi.org/10.1175/BAMS-D11-00070.1, 2012.

Reichle, R. H., Koster, R. D., De Lannoy, G. J. M., Forman, B. A., Liu, Q., Mahanama, S. P. P., and Touré, A.: Assessment and Enhancement of MERRA Land Surface Hydrology Estimates, J. Climate, 24, 6322-6338, https://doi.org/10.1175/JCLI-D-1005033.1, 2011.

Rennermalm, A. K., Smith, L. C., Stroeve, J. C., and Chu, V. W.: Does sea ice influenced Greenland ice sheet surface melt?, Environ. Res. Lett., https://doi.org/10.1088/1748-9326/4/2/024011, 2009.

Rienecker, M. M., Suarez, M. J., Gelaro, R., Todling, R., Bacmeister, J., Liu, E., Bosilovich, M. G., Schubert, S. D., Takacs, L., Kim, G.-K., Bloom, S., Chen, J., Collins, D., Conaty, A., 
da Silva, A., Gu, W., Joiner, J., Koster, R. D., Lucchesi, R., Molod, A., Owens, T., Pawson, S., Pegion, P., Redder, C. R., Reichle, R., Robertson, F. R., Ruddick, A. G., Sienkiewicz, M., and Woollen, J.: MERRA - NASA's Modern-Era Retrospective Analysis for Research and Applications, J. Climate, 24, 36243648, https://doi.org/10.1175/JCLI-D-11-00015.1, 2011.

Rinke, A., Maslowski, W., Dethloff, K., and Clement, J.: Influence of sea ice on the atmosphere: A study with an Arctic atmospheric regional climate model, J. Geophys. Res., 111, D16103, https://doi.org/10.1029/2005JD006957, 2006.

Screen, J. A. and Simmonds, I.: The central role of diminishing sea ice in recent Arctic temperature amplification, Nature, 464, 1334-1337, https://doi.org/10.1038/nature09051, 2010.

Serreze, M. C., Holland, M. M., and Stroeve, J.: Perspectives on the Arctic's Shrinking Sea Ice Cover, Science, 16, 1533-1536, 2007.

Serreze, M. C., Barrett, A. P., Stroeve, J. C., Kindig, D. N., and Holland, M. M.: The emergence of surface-based Arctic amplification, The Cryosphere, 3, 11-19, https://doi.org/10.5194/tc-311-2009, 2009.

Serreze, M. C., Barrett, A. P., and Cassano, J. J.: Circulation and surface controls on the lower tropospheric air temperature field of the Arctic, J. Geophys. Res., 116, D07104, https://doi.org/10.1029/2010JD015127, 2011.

Serreze, M. C., Stroeve, J., Barrett, A. P., and Boisvert, L. N.: Summer atmospheric circulation anomalies over the Arctic Ocean and their influences on September sea ice extent: A cautionary tale, J. Geophys. Res.-Atmos., 121, 11463-11485, https://doi.org/10.1002/2016JD025161, 2016.

Stroeve, J. C., Serreze, M. C., Barrett, A., and Kindig, D. N.: Attribution of recent changes in autumn cyclone associated precipitation in the Arctic, Tellus A, 63, 653-663, https://doi.org/10.1111/j.1600-0870.2011.00515.x, 2011.

Stroeve, J. C., Serreze, M. C., Kay, J. E., Holland, M. M., Meier, W. N., and Barrett, A. P.: The Arctic's rapidly shrinking sea ice cover: A research synthesis, Clim. Change, 110, 1005-1027, https://doi.org/10.1007/s10584-011-0101-1, 2012.

Stroeve, J. C., Crawford, A. D., and Stammerjohn, S.: Using timing of ice retreat to predit timing of fall freezeup in the Arctic, Geophys. Res. Lett., 43, 6332-6340, https://doi.org/10.1002/2016GL069314, 2016.

Stroeve, J. C., Markus, T., Boisvert, L., Miller, J., and Barrett, A.: Changes in Arctic Melt Season and Implications for Sea Ice Loss, Geophys. Res. Lett., 41, 1216-1225, https://doi.org/10.1002/2013GL058951, 2014.

Stroeve, J., Frei, A., McCreight, J., and Ghatak, D.: Arctic sea-ice variability revisited, Ann. Glaciol., 48, 71-81, https://doi.org/10.3189/172756408784700699, 2008.

Tedesco, M.: Snowmelt detection over the Greenland ice sheet from SSM/I brightness temperature daily variations, Geophys. Res. Lett., 34, L02504, https://doi.org/10.1029/2006GL028466, 2007.
Tedesco, M., Serreze, M., and Fettweis, X.: Diagnosing the extreme surface melt event over southwestern Greenland in 2007, The Cryosphere, 2, 159-166, https://doi.org/10.5194/tc-2-159-2008, 2008.

Tedesco, M., Fettweis, X., van den Broeke, M. R., van de Wal, R. S. W., Smeets, C. J. P. P., van de Berg, W. J., Serreze, M. C., and Box, J. E.: The role of albedo and accumulation in the 2010 melting record in Greenland, Environ. Res. Lett., 6, 014005, https://doi.org/10.1088/1748-9326/6/1/014005, 2011.

Tedesco, M. and Fettweis, X.: 21st century projections of surface mass balance changes for major drainage systems of the Greenland ice sheet, Environ. Res. Lett., 7, 045405, https://doi.org/10.1088/1748-9326/7/4/045405, 2012.

Tedesco, M., Fettweis, X., Mote, T., Wahr, J., Alexander, P., Box, J. E., and Wouters, B.: Evidence and analysis of 2012 Greenland records from spaceborne observations, a regional climate model and reanalysis data, The Cryosphere, 7, 615-630, https://doi.org/10.5194/tc-7-615-2013, 2013.

Tedesco, M., Fettweis, X., and Alexander, P. M.: MAR v3.2 regional climate model data for Greenland (1958-2013), UCAR/NCAR CISL - ACADIS, https://doi.org/10.5065/D6JH3J7Z, 2015.

van den Broeke, M., Bamber, J., Ettena, J., Rignot, E., Schrama, E., van de Berg, W.-J., van Meijgaard, E., Velicogna, I., and Wouters, B.: Partitioning recent Greenland mass loss, Science, 326, 984 986, https://doi.org/10.1126/science.1178176, 2009.

van den Broeke, M. and Gallée, H.: Observation and simulation of barrier winds at the western margin of the Greenland ice sheet, Q. J. R. Meteorol. Soc., 122, 1365-1383, https://doi.org/10.1002/qj.49712253407, 1996.

van Tricht, K., Lhermitte, S., Lenaerts, J. T. M., Gorodetskaya, I. V., L'Ecuyer, T. S., Noël, B., van den Broeke, M. R., Turner, D. D., and van Lipzig, N. P. M.: Clouds enhance Greenland ice sheet meltwater runoff, Nat. Commun., 7, 10266, https://doi.org/10.1038/ncomms10266, 2016.

Wang, J., Zhang, J., Watanabe, E., Ikeda, M., Mizobata, K., Walsh, J. E., Bai, X., and Wu, B.: Is the dipole anomaly a major driver to record lows in Arctic summer sea ice extent?, Geophys. Res. Lett., 36, L05706, https://doi.org/10.1029/2008GL036706, 2009.

Yulaeva, E., Schneider, N., Pierce, D. W., and Barnet, T. M.: Modeling of North Pacific Climate Variability Forced by Oceanic Heat Flux Anomalies, J. Climate, 14, 4027-4046, https://doi.org/10.1175/15200442(2001)014<4027:MONPCV>2.0.CO;2, 2001.

Zib, B. J., Dong, X., Xi, B., and Kennedy, A.: Evaluation and Intercomparison of Cloud Fraction and Radiative Fluxes in Recent Reanalyses over the Arctic Using BSRN Surface Observations, J. Climate, 25, 2291-2305, https://doi.org/10.1175/JCLI-D-1100147.1, 2012 